\title{
Milk Protein Synthesis in the Lactating Mammary Gland: Insights from Transcriptomics Analyses
}

\author{
Massimo Bionaz, Walter Hurley and Juan Loor
}

Additional information is available at the end of the chapter

http://dx.doi.org/10.5772/46054

\section{Introduction}

In recent years, and with the advent of more advanced molecular techniques, a compelling case has been made for more in-depth studies of molecular regulation of lactation, particularly in livestock species [1-3]. One of the underlying premises is that advances in our knowledge of the key control points regulating milk component synthesis in the mammary gland, e.g. milk protein, could only be made through more mechanistic studies focusing not only on large-scale mRNA expression [4] but also on post-translational events, e.g. phosphorylation/dephosphorylation of key proteins. The combination of the accumulated knowledge of regulatory mechanisms of milk protein synthesis in recent years has opened new frontiers where intervention may be made in order to improve milk protein synthesis.

\section{Nutrition and milk protein synthesis}

The synthesis of proteins requires the constituents of the protein synthesis machinery, as well as the availability of amino acids and a large supply of energy. Protein synthesis and turnover has a high-energy requirement and after ion transport is one of the most energetically costly processes in the cell. This is evidenced by the reduction of protein synthesis and ion transport during anoxic intervals (reviewed in [5]) but also by the decrease of overall protein synthesis as consequence of caloric restriction (reviewed in [6]). In mammals, the basal energy expenditure for maintenance of ion transport and protein resynthesis has been estimated to be $30-40 \%$ and $9-12 \%$, respectively [7].

The need of energy and protein during lactation increases dramatically. In dairy cows there is more than a 5-fold increase in energy and protein requirement from late gestation to lactation [8]. The fractional synthesis rate in the mammary gland of goats increases ca. 7-fold 
from the dry period to lactation, with synthesis of milk protein accounting for ca. $60 \%$ of the overall proteins synthesized in that tissue [9]. Recently, the use of more precise measurements has estimated that daily tissue protein synthesis (i.e., non-milk protein in mammary tissue) can represent up to $88 \%$ of the total protein synthesized in the goat mammary gland, which uses half of the available ATP supply generated in the lactating udder [10]. In the bovine, there is a 4-fold increase in mRNA translation in lactating compared to non-lactating mammary tissue [11]. The efficiency to transform dietary nitrogen into milk proteins is low (25-30\%) [12]. The estimated fractional protein synthesis rate in the goat mammary gland is $42-130 \%$ and the turnover of the protein contributes $42-$ $72 \%$ of the total (milk included) protein synthesized in the mammary gland [12]. Thus, protein synthesis is a highly active and energetically costly process, with only a minor part of the synthetic machinery apparently being used for production of milk proteins [10].

Milk protein yield is of great significance for the dairy industry. The amount and composition of proteins in milk is largely determined by the genetics of the animal, and is difficult to change through nutrition. However, due to the high requirement of protein synthesis for energy, the milk protein yield can be affected by the energy content in the diet [13]. This has been observed in dairy cows and sheep where energy in the diet was increased or decreased by feed restriction, and both overall protein yield and percentage were affected [14-17]. In the cow the effect is quite consistent. However, in sheep the direct relationship between feed intake and milk protein is not as consistent; for instance, some reports found that feeding a higher energy level compared with a low energy diet resulted in lower milk protein [18, 19]. In rodents, feed restriction significantly decreased milk production, and milk protein yield, but not the percentage of milk protein [20]. Interestingly, feed restriction and, in a more acute way, starvation, decreased mRNA synthesis of genes coding for milk proteins in rats [21]. The mRNA synthesis of those proteins fully recovered by re-feeding, indicating that the regulation of milk protein synthesis is, at the least in part, driven by a transcriptomic adaptation rather than driven only by availability of energy. There is also an inverse relationship between dietary fat content and milk protein production, as observed in dairy cows and sheep (reviewed in [15, 17]). Interestingly, the treatment of lactating animals with trans10,cis12-conjugated linoleic acid (t10,c12-CLA), a long-chain fatty acid (LCFA) with a well-established negative effect on milk fat production [22], increases production of milk and milk protein. This has been observed in grazing dairy cows (i.e., that are considered to have a limited energy intake) [23] and fed-restricted ewes [24]. The increase of milk protein by t10,c12-CLA treatment appears to be associated with a greater metabolizable energy availability due to the decrease of fat synthesis in the mammary gland and other peripheral organs, such as adipose [24, 25]. Overall, all the above reported studies support the large dependence of mammary milk protein synthesis on the availability of energy.

Along with the availability of energy, the availability of amino acids (AA) is critical for mammary protein synthesis. Earlier studies carried out to evaluate the effect of increasing dietary protein of dairy cows have failed to demonstrate a consistent positive effect on milk protein (reviewed in [26]). The rumen contains a large population of active microbes that 
use dietary proteins for their own metabolism, changing the composition of the available AA reaching the intestine. Post-ruminal infusion of casein can preserve its high biological value for milk protein synthesis, and theoretically, should provide the optimal composition of AA for milk protein synthesis. Post-ruminal infusion of casein has been reported to result in a general increase in milk protein synthesis [13,27], however this is accompanied by a decrease in efficiency as the amount of infused protein is increased and resulting in a lower effect compared to dietary energy [27]. In further support of the importance of energy compared to AA supply, abomasal infusion of casein alone failed to increase milk protein yield, while infusion of starch significantly increased milk protein yield [28]. In vitro studies evaluating protein synthesis in bovine mammary acini cultures also indicate an effect of available energy on protein synthesis [29]. All the above studies support a significant role of energy availability for bovine milk protein synthesis and a smaller role for overall AA availability. In contrast, increases in dietary protein results in greater milk and milk protein yield in lactating sows [30].

Nevertheless, the availability of specific AA can be a limiting factor for milk protein synthesis [12, 13]. Among the many AA essential for the lactating bovine mammary gland $[13,28,31]$, methionine and lysine are considered the most important [12, 32]. The AA in mammary gland in dairy cows are not solely used for protein synthesis, but also for production of energy through the Krebs cycle $[12,33]$. Our recent transcriptomics studies in dairy cattle from pregnancy to lactation support that conclusion [34].

The positive effect of dietary energy on milk protein synthesis is partly a result of the availability of energetic precursors to produce intracellular energy transfer molecules (e.g., ATP, GTP, NADH, and NADPH). Another important role of energy is through the increase in insulin secretion as a consequence of greater dietary energy. A positive role of insulin in milk protein synthesis has long been recognized [35]. A strong positive effect of insulin on yield of milk protein was demonstrated in dairy cattle with chronically elevated insulinemia through the use of hypeinsulinemic-euglycemic clamp experiments (reviewed in [36]). The role of insulin in increasing milk protein is considered problematic in dairy cows due to the dramatic decrease in blood concentration of this hormone at the onset of lactation which remains low for at least the first two months post-partum [37], a period which coincides with peak milk yield. However, the pattern of insulinemia during lactation [37] appears to follow the pattern of milk protein concentration [4]. Recently, insulin has been demonstrated to play a key role in milk protein synthesis both in mice [38] and dairy cows [39]. Our own studies also support a pivotal role of insulin in milk protein synthesis [4]. The potential mechanisms are discussed in more detail in Section 5.

In summary, milk protein synthesis can be fine-tuned by nutrition through increased availability of metabolized energy (e.g., by feeding t10,c12-CLA besides increasing energy content in the diet and/or food intake) and specific AA. Metabolizable energy appears to be the most important factor through provision of energetic precursors for the protein synthesis process, but also through increasing insulin (and perhaps also insulin-like growth factor 1 , see below), which in turn positively affect the protein synthesis signaling network. 


\section{Transcriptomics: a novel approach to study biology}

The classically-considered transcripts (i.e., mRNA; that reflected the classical transcriptome until the discovery of large transcription of non-coding RNAs) encode genetic information about proteins; thus, the changes in expression of the genes making up the transcriptome can exert major influences on physiological functions. The transcriptomics in biology has expanded our knowledge at an unprecedented pace, and essentially forced the scientific community to embrace the notion of holism as it relates to animal function. The term "functional genomics" is generally defined as the study of the functions of genes, related proteins, and activity (i.e., metabolomics) [40]. Most of the functional genomics studies have been carried out using transcriptomics with the intent, besides determining/confirming functions of genes, to infer biological adaptation, i.e., by comparing the transcriptome in different conditions it is possible to infer the biological adaptation of cells, tissue, or organs. The study of the transcriptome has classically being carried out via DNA microarray technology, and more recently, via Next Generation Sequencing. The latter, while relatively new, appears to be replacing microarrays as the tool of choice for functional genomics studies in livestock [41]. Both approaches allow the simultaneous monitoring of the expression of most or, particularly for the latter, the entire transcriptome in tissues or cells. Currently-available types of microarray platforms include cDNA microarrays (usually pure products from PCR amplification of cDNA and EST clones that are $100-2,000$ nucleotides long), oligonucleotide microarrays (60-70 nucleotides per DNA synthesized from singlestranded probes on the basis of sequence information in databases), and commercial platforms such as the Affymetrix GeneChips (35-200 nucleotides per DNA) or the Agilent whole-transcriptome microarray.

The so-called "bottom-up" or "top-down" approaches have been used successfully in model organisms to study the metabolic behavior at the cellular level. Whereas, the bottom-up approach relies on developing automated tools based on a mathematical model, the topdown approach encompasses data processing from 'omics' studies to pathways and individual genes of an organism [42]. In essence, the cell can be approached from both bottom to top (universality) or from top to bottom (organism specificity) equally well, i.e., from molecules to the scale-free networks or modules, or moving from a network scale-free and hierarchical nature to organism-specific modules [43].

The top-down approach originates from the transcriptome experimental data and information used to reconstruct metabolic models. This approach can help to unravel biological behavior and underlying interactions using 'omics' data which can be obtained via DNA microarrays [44], RNA sequencing (RNA-seq) [45] or other genome-enabled technologies. The flow of information in the top-down approach occurs from transcriptome and proteome to flux-balanced metabolic pathways [46]. This approach aims to discover new functional aspects of cellular behavior from the 'omics' data sets through the standard top-down methodologies. By default, this approach covers the whole genome, thus, it is considered as a "potentially complete" approach, i.e., it deals with all the genome-wide transcriptomic information [42,47]. This has been widely used in model organisms during the past 15 years, and resulted in major advancement of regulatory metabolic networks [48]. 


\begin{tabular}{|c|c|c|c|c|c|c|c|c|}
\hline & Cow & Mouse & Rat & Human & Pig & Sheep & Goat & Kangaroo \\
\hline Body Weight (kg) & 650 & 0.04 & 0.25 & 60 & 170 & 70 & 65 & 50 \\
\hline$M G^{\$}$ weight $(g)$ & 25,000 & 2.7 & 17.8 & 1,000 & 6,000 & 1,400 & 1,200 & -- \\
\hline$\% M G / B W(\mathrm{~kg} / \mathrm{kg})$ & 3.8 & 7.5 & 7.1 & 2.5 & 3.5 & 2.0 & 1.8 & -- \\
\hline Milk yield $(g / d)$ & 40,000 & 6 & 43 & 600 & 10,000 & 2,000 & 4,500 & 50 \\
\hline Dry matter (DM) (\%) & 12.4 & 29.3 & 22.1 & 12.4 & 20.1 & 18.2 & 12.0 & 23.5 \\
\hline g milk/kg BW & 61 & 150 & 172 & 10 & 59 & 29 & 40 & 1 \\
\hline g milk/g MG & 1.6 & 2.2 & 2.4 & 0.6 & 1.7 & 1.4 & 1.7 & -- \\
\hline Day of lactation & 305 & 20 & 20 & 365 & 45 & 200 & 305 & 340 \\
\hline$g$ DM milk/kg BW & 7.6 & 44.0 & 38.0 & 1.2 & 11.8 & 5.2 & 8.3 & 0.2 \\
\hline g DM milk/kg MG & 198.4 & 651.1 & 533.9 & 74.4 & 335.0 & 260.0 & 450.0 & -- \\
\hline Parturition/year & 1 & 8 & 5 & 1 & 2 & 1 & 1 & 1 \\
\hline
\end{tabular}

\begin{tabular}{|c|c|c|c|c|c|c|c|c|}
\hline & B/Rg & & & & & & & \\
\hline Total Proteins & 28.9 & 111.5 & 84.0 & 11.7 & 53.0 & 62.1 & 34.5 & 35.8 \\
\hline Caseins & 23.8 & 90.3 & 64.0 & 4.0 & 29.0 & 51.6 & 29.4 & 16.1 \\
\hline$\alpha-S 1$ & 9.1 & 25.0 & -- & -- & -- & -- & -- & 19.6 \\
\hline$\alpha-S 2$ & 2.4 & -- & -- & -- & -- & -- & -- & -- \\
\hline$\beta$ & 8.5 & 26.0 & -- & -- & -- & -- & -- & 11.5 \\
\hline$\kappa$ & 3.0 & -- & -- & -- & -- & -- & -- & -- \\
\hline Whey proteins & 3.0 & 21.2 & 20.0 & 7.6 & 20.0 & 8.1 & 5.1 & 8.1 \\
\hline$\alpha$-Lactalbumin & 1.1 & -- & 1.0 & 6.1 & 2.6 & -- & 1.7 & 2.1 \\
\hline$\beta$-Lactoglobulin & 2.8 & -- & -- & -- & -- & -- & -- & -- \\
\hline Albumin & 4.0 & 15.0 & -- & 0.3 & -- & -- & -- & -- \\
\hline Lactoferritin & $<0.1$ & -- & -- & 2.8 & -- & -- & -- & -- \\
\hline Casein/Whey protein & 7.9 & 4.2 & 3.2 & 0.5 & 1.4 & 6.3 & 5.7 & 2.0 \\
\hline
\end{tabular}

Protein content relative to several other parameters

\begin{tabular}{|c|c|c|c|c|c|c|c|c|}
\hline$g / d a y$ & 1156.0 & 0.7 & 3.6 & 11.7 & 530.0 & 124.2 & 155.2 & 1.8 \\
\hline g/day protein synth. ${ }^{* *}$ & 2196.0 & 0.8 & -- & -- & 975.1 & -- & 241.0 & -- \\
\hline$\%$ Milk protein/synth. & 52.6 & 87.5 & -- & -- & 54.3 & -- & 64.0 & -- \\
\hline kg/lactation & 352.6 & 0.01 & 0.1 & 4.3 & 23.9 & 24.8 & 47.4 & 0.6 \\
\hline $\mathrm{kg} / \mathrm{lact} / \mathrm{kg} \mathrm{BW}$ & 0.5 & 0.4 & 0.3 & 0.07 & 0.1 & 0.4 & 0.7 & 0.01 \\
\hline g/day/kg MG & 46.2 & 247.8 & 202.9 & 7.8 & 88.3 & 88.7 & 129.4 & -- \\
\hline $\mathrm{kg} / \mathrm{lact} / \mathrm{kg} \mathrm{MG}$ & 14.1 & 5.0 & 4.1 & 2.8 & 4.0 & 17.7 & 39.5 & -- \\
\hline kg $x \#$ Lact/year/kg BW & 0.5 & 3.0 & 1.4 & 0.07 & 0.3 & 0.4 & 0.7 & 0.01 \\
\hline
\end{tabular}

*Estimates were made knowing that there is large variation between breed of animals and among human populations; data are based on references [50-63]; ${ }^{* *}$ Measured protein synthesis rate (or averaged among different stages of lactation) as reported in reference [64] for pig, [10] for goat, and [65] for mouse. For cows and goats it has been reported that the protein synthesis in mammary gland is between 1.3 to 2.5 the rate of milk protein secretion $[12,66]$; thus, for cow an average of 2.0 was used.

\$Mammary Gland (MG). General references [67, 68]. Specific references for milk composition are: bovine [4, 67, 69], mouse and rat [70-74], human [75], pig [55], sheep and goat [76], and Kangaroo [77-79]

Table 1. Estimated* body weight, milk protein composition, and total protein relative to other parameters in several species. Reported are the total proteins and the major protein fractions. 
The application of functional genomics and bioinformatics allows for a thorough exploration of the biological complexity of organisms' tissues [34]. Together, these approaches form part of the systems biology framework, i.e., a way to systematically study the complex interactions in biological systems using a method of integration instead of reduction. One of the goals of applying systems concepts is to discover new emergent properties that may arise from examining the interactions between all components of a system to arrive at an integrated view of how the animal functions. It has been argued previously $[3,49]$ that application of the systems approach might lead to the discovery of regulatory targets that could be tested further (i.e., model-directed discovery) or help address a broader spectrum of basic and practical applications including interpretation of phenotypic data, metabolic engineering, or interpretation of lactation phenotypes.

\section{Expression of genes coding for main milk proteins in lactating mammary gland}

\subsection{Introduction}

The main proteins in milk are caseins and whey proteins (i.e., alpha-lactalbumin, betalactoglobulin, whey acidic protein [WAP], albumin, and immunoglobulin; proteins highly enriched in the milk serum after removal of casein). The milk protein content and composition of the main milk proteins with abundance of each of the caseins and whey proteins in several species (when available) is summarized in Table 1.

The milk fat globule membrane (MFGM) is also highly enriched with proteins even though those account for only $1-4 \%$ of total protein in the milk [80]. Reinhardt and Lippolis identified 120 proteins in an proteomics analysis of the bovine MFGM [81]. More recently, the same authors have compared the MFGM proteome between colostrum and milk and found 138 proteins in the MFGM [82]. Analysis of two MFGM-enriched milk fractions, a whey protein concentrate (WPC) and a buttermilk protein concentrate (BMP), identified as the major proteins associated with the WPC immunoglobulin $\mathrm{k}$, lactoperoxidase, serpin A1, immunoglobulin lambda light chain variable region (Vl1a protein), serum albumin, lactoferrin, and CD9; and the most abundant associated with the BMP, besides caseins, were adipophilin, tripartite motif containing 11, and folate receptor [83]. The fraction enriched in BMP known to be part of the MFGM [80, 81], besides adipophilin, were lactadherin (PAS 6/7 or milk fat globule-EGF factor 8 protein or MFGE8), xanthine dehydrogenase, butyrophilin, and fatty acid binding protein [83]. The major MFGM proteins are mostly involved in the milk secretion, particularly the secretion of milk fat globules [84]. There are, however, many proteins present in a minor amount. Among those, of relatively high abundance are CD36 and mucin proteins $[80,81]$. While a specific biological role for all the proteins associated with the BMP and WPC has not been clearly defined, it appears that at the least some of the latter proteins play a role in the defense mechanisms in the newborn and some appear to be related to human/animal health, particularly lactoferrin [80, 83, 85-87].

We have used the data in Table 1 to estimate the milk protein synthesis rate for the respective species. It is evident that rodents, and particularly mice, have the richest amount of proteins in 
milk among the compared species. Compared with cows, mice and rats have more than twice as much milk production per body weight (BW), from 3 to 6 -fold more milk production considering the milk solid relative to the BW or weight of mammary gland, and more than 5fold more milk protein synthesis per weight of mammary gland (Table 1). Therefore, rodents have, compared with cows, an extraordinary milk protein synthesis rate (based on the rough estimate in Table 1, each mammary epithelial cell in the lactating mouse produces and secretes approximately a quarter of its weight in milk protein per day). The mouse has an estimated rate of protein synthesis that is 5-fold greater than that estimated for the cow, and ca. 100-fold greater than estimated for humans (see Table 1). Overall, the monogastrics appear to have on average a greater rate of milk protein synthesis compared with ruminants, although sheep and goats are estimated to have a synthesis rate equal or greater than pigs (Table 1). The estimates offered in Table 1 have to be considered indicative and do not account for the proportion of epithelial cells in the mammary weight and the amount of degraded proteins, thus, those are underestimates of the mammary epithelial milk protein synthesis rates.

Milk yield, milk composition, energy output by lactation, and mammary gland weight for several species were reviewed more than 25 years ago $[62,68]$. Some of those same data have been used in the present chapter. In those reviews it was shown that there is a linear correlation between either maternal weight and milk energy yield (i.e., larger the size of the animal greater the milk energy output, with an increase of milk energy output with number of litters), or mammary gland weight with milk yield. Linzell [62] suggested that the milk yield per $\mathrm{kg}$ of mammary tissue does not differ between species. Our data reported in Table 1 appear to come to a different conclusion. For instance, for Linzell, the mammary gland weight over BW is slightly lower in the mouse than in the Holstein cow, but our calculation in Table 1 showed that the mammary gland of the mouse is ca. $7 \%$ of $\mathrm{BW}$ while in high producing dairy cows it is only ca. $4 \%$ of BW. The same is true for the productive capacity of the mammary gland. From Linzell, the amount of milk per mass of mammary gland is similar among all species, but, from our calculation (Table 1), rodents have a greater capacity for milk synthesis compared with other species, particularly the high producing dairy cow. Our data, however, are consistent with the known greater uptake of oxygen (i.e., metabolism) in the mammary gland of smaller relative to larger animals (cited in [62]).

\section{2. mRNA abundance and expression patterns of transcripts coding for milk proteins}

The abundance of the milk proteins (with the exception of albumin, as discussed below) is highly-dependent on the transcription level, with additional important regulatory roles for translational and post-translational modifications [88]. In Figure 1 are reported the temporal patterns of transcription of caseins, alpha-lactalbumin, whey acid protein, and albumin from pregnancy to lactation in two ruminant species (dairy cow [89] and dairy goat [90]), two monogastric species (mouse [91] and pig [92]), and a marsupial (kangaroo; Macropus eugenii [93]). Those were the only microarray datasets publicly available at the time of this writing. In Figure 2 is reported the expression pattern from pregnancy to lactation for other proteins found to be associated with the MFGM, BMP, and/or WPC [80, 81, 83]. 
The temporal expression pattern of all the casein genes was similar, and was consistent for the two ruminant species, with CSN1S2 followed by the CSN1S1 as the most up-regulated casein genes in both species and with an overall greater up-regulation of casein genes in the cow relative to the goat (Figure 1). Alpha-lactalbumin was similarly up-regulated in all species except kangaroo (Figure 1). Both monogastrics had a large increase in expression of CSN1S2 during lactation, with the mouse having a particularly large increase of the Csn1s2b isoform (Figure 1).

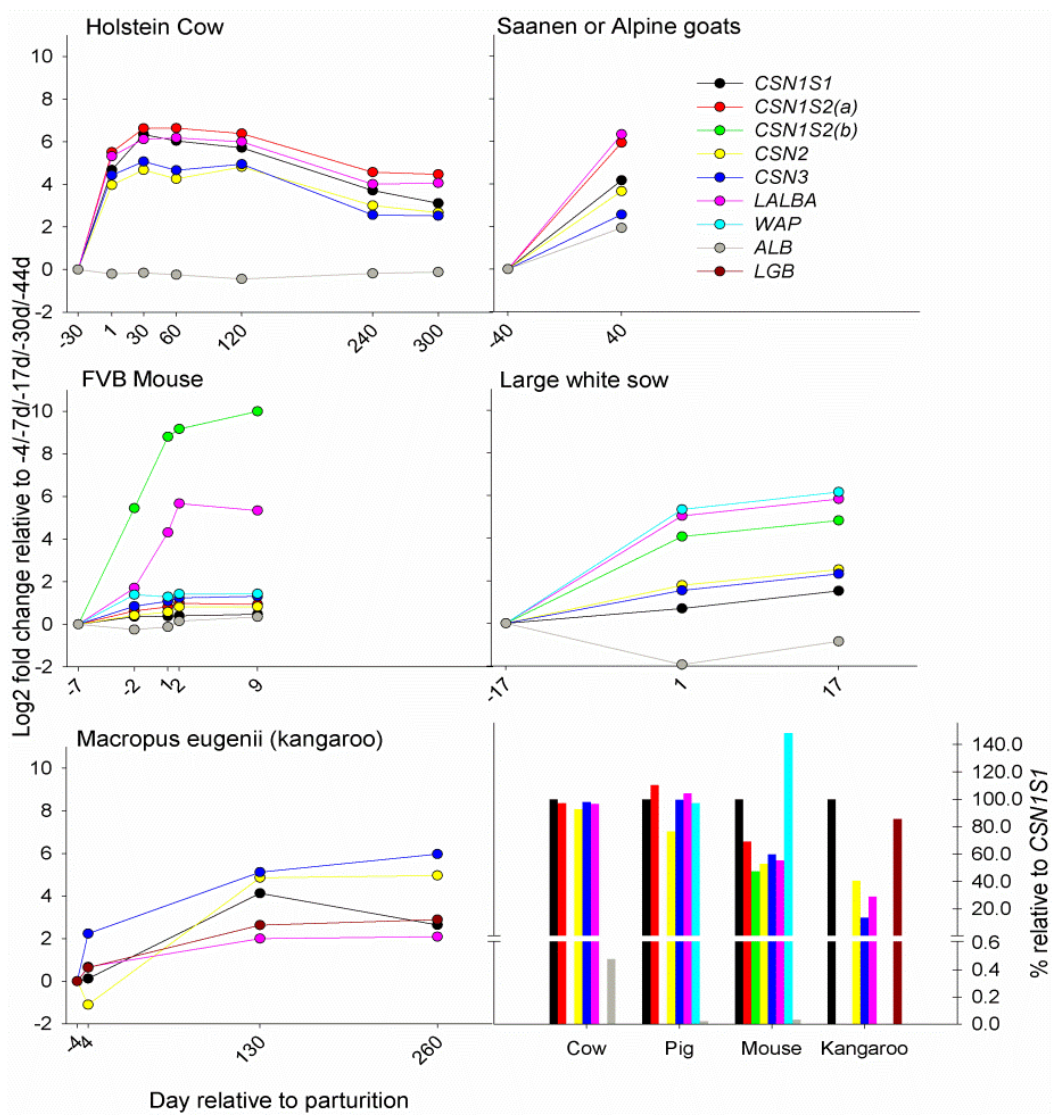

Figure 1. Temporal expression pattern of genes encoding casein alpha-S1, casein alpha-S2 (for mouse the genes are casein alpha s2-like A and casein alpha s2-like B), casein beta, casein kappa (CSN1S1, CSN1S2- (a) and (b) for mouse -, CSN2, and CSN3, respectively), alpha-lactalbumin (LALBA) and albumin $(A L B)$ in dairy cows [89], mouse [91], pig [92], goat [90], and kangaroo (Macropus eugenii; [93]). Dataset, except for dairy cows and kangaroo, was obtained through NCBI Gene Expression Omnibus (GEO at http://www.ncbi.nlm.nih.gov/geo/): GSE14008 for goat, GSE4222 for mouse, and GSE30704 for pig. Data from the Series Matrix File were used. A statistical analysis using a false discovery rate for the overall time effect was run using GeneSpring GX7.. Data for the kangaroo are from [93]; only one isoform of alpha casein was reported. Important whey protein components such as immunoglobulin genes are not reported in the present figure. Expression of beta-lactoglobulin was only reported for the Kangaroo [93]. The relative mRNA abundance between the caseins, $L A L B A$, and ALB is 
also reported. Those data should be evaluated with caution because microarray platforms do not provide an absolute abundance value for each mRNA. This is due to technical reasons, such as the fact that the DNA oligos complementary for each cDNA used in the platforms can bind the cDNA with different efficiency and also because the highly expressed proteins can saturate the spot with consequent oversaturation and bleaching during microarray scanning. Despite those limitations, there is a relatively good agreement between the abundance of mRNA and microarray signal (i.e., number of cDNA with dyes bound to the oligos); thus, despite not being absolute, the comparison between microarray signals can be used to provide an initial idea of relative abundance between mRNA species. The high similarity in relative transcript abundance among caseins and between casein genes and alpha- lactalbumin in mammary gland of dairy cows is consistent with transcriptomics analysis of bovine milk somatic cells using the more accurate RNA sequencing technology [94]. In the figure are reported the relative percentage of the signal of the genes of interest compared to CSN1S1 or Csn1s1. For the kangaroo, the percentage of beta-lactoglobulin mRNA compared to CSN1S1 is also reported, and for the mouse, the relative abundance of Csn1s2a is reported (the Csn1s2b mRNA abundance is $47.5 \%$ of $C s n 1 s 1$ ). The lack of data for some genes is a consequence of the absence of the respective oligos on the microarray. The gene symbols of the legend are in capital and italic as should be reported for cow, pig, and goat. Gene symbols for the mouse should be only first capital letter and not italic. All genes were deemed to be significantly affected by time with a false discovery rate $<0.10$ [95] based on analysis using GeneSpring GX7 (Agilent). Exception was the $A L B$ for the pig. For the kangaroo and the goat it was not possible to obtain the statistical data.

The other caseins, despite being significantly affected by time, were not highly up-regulated by lactation in those species. Also, the monogastric had a large increase in expression of WAP especially for pig, where the increase in expression was proportional to LALBA (Figure 1). The relative mRNA abundance of WAP appears to be as high as or higher than caseins in monogastric, particularly in the mouse (Figure 1).

In the kangaroo all transcripts coding for caseins had a greater increase in expression compared with $L A L B A$ which was up-regulated but only in a small magnitude during lactation in this species. The low importance of alpha-lactalbumin in this species has been previously established and its presence in milk does not change throughout lactation [78]. This is in line with the relatively low amount of lactose in the milk of the kangaroo [78, 96, 97].

It has been considered for a long time that the albumin present in bovine milk, which is probably identical to the serum albumin, is present as a consequence of permeability of the epithelial lining in the mammary gland. However, other evidence suggested that the goat mammary gland is able to synthesize a portion of the milk albumin [98]. Expression of albumin in the bovine mammary gland has been previously reported and studied in dairy cows [99]. Observations of increased albumin expression in mammary tissue explants challenged with lipopolysaccharides, and a higher expression observed in glands with mastitis, have led to the suggestion that albumin may have a role in the innate nonspecific defense system [99]. In all species where albumin mRNA was available (i.e., all except kangaroo, Figure 1) a level of expression was detected by the microarray platforms even though at very low levels compared to the highly abundant milk proteins. Interestingly, even when considering the limitations of the relative abundance between measured genes in Figure 1 (see Figure 1 caption), the dairy cow appears to have a relatively higher expression of $A L B$ compared to the mouse and pig, where it is virtually absent (Figure 1). The 
expression of albumin decreased slightly, but significantly, in lactation compared to pregnancy in dairy cows (Figure 1). Milk content of albumin decreases rapidly during the first month of lactation, followed by a slight but steady increase up to 6 months of lactation, then rapidly decreasing reaching a nadir at around 200 day in milk [100]. The gene expression data support a basic, although low, expression of albumin in the mammary gland, however, the importance of this expression in the lactating gland is unclear.

The pattern in expression of the other major proteins in milk during pregnancy and lactation in several species is shown in Figure 2. Among the genes coding for proteins highly enriched in the WPC, mostly involved in the innate immune response [101], the data clearly shows that the mouse and pig have a large increase in expression of only lactoferrin (LTF), while the goat has a large increase in expression only for lactoperoxidase and a decrease in expression of LTF (Figure 2). Those data appear to be supported by an increase of milk lactoperoxidase content through lactation in goat [102]. Dairy cows have a moderate, although consistent, increase only for the genes coding for lactoperoxidase and lactoferrin (Figure 2). Collectively, those data might indicate an overall increase in the innate immune response of the mammary gland during lactation [103] and/or an increase in milk antimicrobial activity in all species during lactation. It appears that the goat, mouse and pig have a higher antimicrobial activity in the milk due to the spike of specific activities (i.e., lactoperoxidase in goat and lactoferrin in monogastric). However, despite the lack of change in expression of LTF from early to peak lactation (Figure 2), the amount of lactoferrin in milk of sows has been reported to peak during colostrogenesis and to decrease thereafter [104], while in the cow lactoferrin concentration in milk has been reported to both increase [105] or decrease [100] as lactation progress.

The expression in the mammary gland of milk proteins related to BMP and/or MFGM (Figure 2) indicates an overall higher increase in expression in the bovine mammary gland compared to the other species evaluated. In particular, there is a large expression of $F A B P 3$. The FABP3 is also called mammary-derived growth inhibitor because it has been known to be highly abundant in the bovine mammary gland [106] and has a high affinity for longchain fatty acids (LCFA), particularly saturated LCFA. This protein may have a dual role in the mammary gland for the synthesis of milk fat, participating in the transfer of LCFA during triacylglycerol synthesis and carrying LCFA into the nucleus for activation of nuclear receptors such as peroxisome proliferator-activated gamma (PPAR $\gamma$ ). The latter nuclear receptor has been suggested to be partly responsible for the transcription of milk fat synthesis-related genes [69]. Expression of FABP3 was significantly affected by stage of lactation in all species. Other BMP proteins for which the expression was generally increased in all species (expect the pig, due to their absence in the microarray platform) are butyrophilin and xanthine dehydrogenase, considered to have a pivotal role in milk fat secretion $[69,81]$. Interestingly, the genes coding for the proteins reported to be among the most abundant in milk after casein and whey proteins [80, 83] all showed an increase in expression during lactation.

The above observations support the importance of transcriptional regulation of the milk proteins, as also previously suggested for dairy cows [34]. However, some of the data (e.g., 
patterns of expression and milk content of LTF in sows) might indicate that the abundance of some of the most enriched proteins in milk is regulated post-translationally, as previously shown [88].

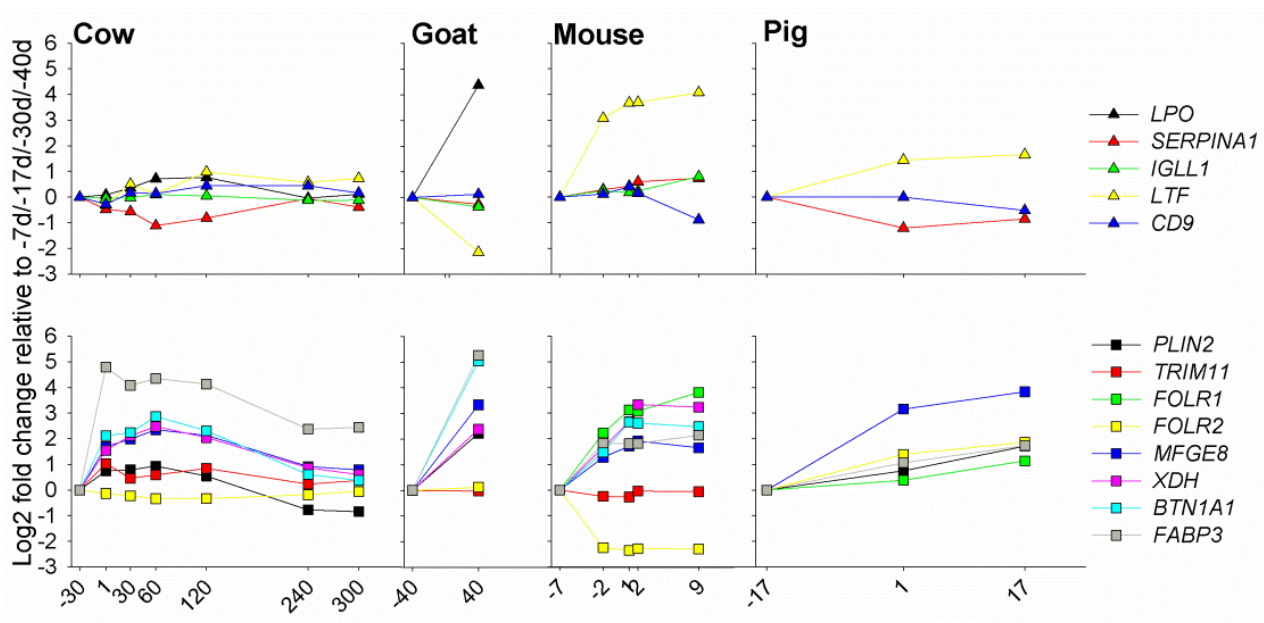

Day relative to parturition

Figure 2. Temporal expression of genes coding for major proteins found in whey protein concentrate (WPC; upper panels) and in the buttermilk protein concentrate (BMP; lower panels) [83]. Data are for Holstein dairy cows [89], Saanen or Alpine goats [90], FVB mice [91] and Large white sows [92]. Data were recovered and treated as reported in the legend for Figure 1. Symbols of the genes denote $L P O=$ lactoperoxidase; SERPINA1 = serpin peptidase inhibitor, clade A (alpha-1 antiproteinase, antitrypsin), member 1; IGLL1 = immunoglobulin lambda-like polypeptide 1; LTF = lactoferrin; and CD9 = CD9 molecule for the genes coding for the WPC related-proteins. Symbol of the genes denote PLIN2 = perilipin 2 or adipophilin; TRIM11 = tripartite motif containing 11; FOLR1 and FOLR2 = folate receptor 1 and 2; MFGE8 = milk fat globule-EGF factor 8 protein or lactadherin; $X D H=$ xanthine dehydrogenase; BTN1A1 = butyrophilin; and $F A B P 3=$ fatty acid binding protein 3 for the genes coding for the BMP related-proteins. The ones in bold font are major MFGM proteins in the BMP fraction. With a FDR $<0.10$ as cut-off for overall time effect, all genes were significantly affected in mouse, while in the pig CD9, FOLR2, IGLL1, SERPINA1 and XDH and in the cow TRIM11 and IGLL1 were not significantly affected by time. It was not possible to obtain the statistical data for the kangaroo and the goat.

\subsection{Regulation of milk protein expression}

It is well-established, at the least in rodents and ruminants, that hormones such as prolactin, growth hormone, insulin, insulin-like growth factor, thyroid hormone, parathyroid hormone, oxytocin, placental lactogen, and glucocorticoids are important, if not essential, in the regulation of lactation and some play an essential role in milk protein expression with noteworthy differences between species [107-109]. For instance in rats, prolactin concentration in plasma increases significantly just before parturition and remains high for the entire lactation [110], accompanied also by a concomitant increase in prolactin receptor [111] which appears similar to the pattern of prolactin receptor in mouse mammary during 
lactation [112]. In contrast, prolactin concentration in dairy cows increases dramatically at the onset of lactation and decreases afterwards to levels observed prior parturition, and prolactin receptor expression does not increase [4].

However, the prolactin concentration is acutely increased by suckling or milking in all species. One large difference between bovine and mouse is the frequency of milk removal. In general, in mouse pups suckle every $20 \mathrm{~min}$ [113] (ca. 72 times/day) while in suckling beef calves (which can be considered the "natural" milk removal in cattle) the frequency is between 3-5 sucklings/day with 5-10 min per suckling [114]. Dairy cows in conventional farms are milked 2-3 times a day with an average of ca. $5 \mathrm{~min} /$ milking [115]. Therefore, in species like the pig, mouse, and rat the higher prolactin concentration is likely due to short intervals pattern of nursing, while in ruminant the low prolactin concentration might be due to the longer nursing intervals. Interestingly, even though most of the lactogenic hormones are present in a relatively high concentration prior parturition, the drop in blood progesterone is essential in order to allow lactogenesis to proceed [108], highlighting the pivotal role of this hormone.

Several transcription factors control expression of the major milk proteins, particularly for caseins [107]. The caseins genes are all present on one chromosome (e.g., chromosome 6 for bovine and chromosome 5 for mouse) and in a cluster of single-copy genes [116]. The alphaand beta-caseins have highly conserved regulatory motifs, while kappa-casein, even though the expression pattern is similar to the other caseins (especially in dairy cows, see Figure 1 as example), does not have similarly conserved regulatory motifs. Most of the investigation in regulation of milk protein expression have been concentrated on beta-casein and WAP in mice [107]. The regulatory motifs found to affect the expression of milk proteins have been reviewed more than a decade ago [107]. At that time it was well-established that the response element for signal transducer and activator of transcription 5 (STAT5), CCAAT/enhancer binding protein $(\mathrm{C} / \mathrm{EBP})$ beta $(\mathrm{CEBPB})$, and glucocorticoid receptor $(\mathrm{GR})$ were essential for inducing transcription of beta-casein and nuclear factor 1 (NF1) was essential for inducing transcription of WAP [107]. The Yin and Yang 1 protein (YY1) instead has a well-known negative effect on beta-casein expression [107]. More recently, octamerbinding transcription factor 1 (Oct1; official gene symbol is Pou2f1) was found to be involved in the expression of beta-casein in the mouse mammary gland [117]. Glucocorticoid receptor and STAT5 cooperate through a protein-protein interaction for the induction of beta-casein expression (reviewed in [118]). Interestingly, using a genetically modified mouse where it was possible to repress the Stat5a expression in the mammary gland during lactation, the repression of Stat5a expression negatively affected the transcription of Wap and Lalba, but not Csn2 [119].

An important role for the control of casein expression appears to be played by the extracellular matrix (ECM) and cell-to-cell adhesion. More than two decades ago it was clearly shown that ECM affects epithelial cell differentiation and function [120]. Cellular interaction with ECM is necessary in order for prolactin to activate STAT5 (reviewed in [107]). This role of ECM in regulation of CSN1S1 expression in rabbit mammary epithelial cells occurs by modifying chromatin structure through the laminin-integrins interaction and 
signaling [121]. The same work showed that, contrary to previously reported studies in mice, the ECM in rabbit epithelial cells activates expression of casein through a mechanism independent from STAT5 or CEBPB. In fact they showed an increase of histone acetylation (i.e., dissociation of histone from DNA allowing the latter to be accessible for transcription factors and polymerase) by the ECM. Very recently is was demonstrated that the RhoA- Rho kinase -myosin II pathway, involved in stress fiber formation, cellular contractility, cell migration, and polarity, has a negative effect on the activation of STAT5 by prolactin in mouse mammary epithelial cells [122]. The same study showed that mammary epithelial cells cultured on plastic or collagen I have a large activation of such pathways and, as a consequence, the stimulation of casein expression by prolactin is strongly impaired.

It is well-known that epithelial cells cultured on plastic do not express or produce caseins [123] but when they are cultured in 3D they regain the ability to express and secrete casein, as seen in porcine primary mammary epithelial cells [124]. Bovine mammary epithelial MAC-T cell line cultured on plastic expresses and releases a low amount of casein into the media [125, 126]; however, the amount released is often below the limit of detection [127]. When MAC-T cells are cultivated on a floating collagen gel the expression and production of casein is augmented dramatically [127]. Interestingly, the addition in the media of growth hormone (besides the presence of the insulin, prolactin, and hydrocortisone, the essential cocktail for milk protein synthesis) strongly induces the expression of casein and alpha-lactalbumin genes in MAC-T cells cultured on plastic with enhanced cell adherence capacity [126], partly contrasting with the findings supporting the importance of ECM (or 3D structure) for the expression of caseins. The dissimilarity also may be due to species differences. In the bovine, STAT5 responds to prolactin and other lactogenic growth factors and its activity increases during lactation mostly due to phosphorylation [128, 129]. However, in the bovine mammary gland when compared to the rodent, the role of STAT5 in controlling milk protein expression through the Jak2-Stat5 signaling pathway appears to be weak at best [130], highlighting a difference between the bovine and the mouse in protein synthesis regulation. It has been proposed that the transcription factor E74-like factor 5 (ELF5), a co-regulator of the STAT5 signaling and a mammary epithelial specific ELF gene, can compensate for the lack of prolactin signaling in inducing lactation and, particularly, milk protein synthesis in mice [131, 132]. Recent data in dairy cows showed a large increase in expression of ELF5 during lactation supporting a major role of this transcription factor in controlling milk protein synthesis, considering that prolactin in this species is higher only at the onset of lactation [4].

In a study carried out in lactating rats, deficiency of prolactin and growth hormone was not as effective in shutting down the expression of casein genes as the removal of the suckling pups suggesting that other local factors are essential and more potent than endocrine in controlling milk synthesis in this species [133]. In mouse mammary epithelial cells the presence of laminin-rich basement membrane (i.e. ECM) was sufficient to induce expression of casein genes without the addition of any growth factor, highlighting the essential role of integrins $[123,134]$. Interestingly, in goat mammary tissue in vivo and in vitro disruption of cell junctions strongly reduced milk yield and expression of casein and alpha-lactalbumin [135]. 
It also has been demonstrated that the expression of milk proteins is strongly under epigenetic regulation (reviewed in [136]). Among several epigenetic mechanisms known (reviewed in [137]) the studies in mammary gland have primarily focused on DNA methylation. The methylation of DNA represses the transcription of genes by two mechanisms, by a steric impediment for the transcription factors to bind to their binding sites or through recruiting methyl-CpG binding proteins that, by engaging additional proteins involved in compacting the DNA, renders the DNA inaccessible for the polymerase [137]. The promoter region of casein genes is hypo-methylated in the mammary gland but hyper-methylated in other tissues. Similarly, the STAT5 promoter region is also hypomethylated in the mammary gland [137]. Interestingly, the methylation status of the casein promoter region is affected by inflammation in the mammary gland. In regard to epigenetic, an active field of research now is the role of hereditary epigenetic patterns and fetal reprogramming in dairy cows and how those account for the performance of the animal, (reviewed in [137]) including expression of genes encoding major milk proteins.

Overall the findings reported above indicate that the regulation of milk protein synthesis is complex and multiple factors work in concert to bring about full activation of expression of genes coding for major milk proteins. The endocrine and mechanical cues independently stimulate expression of a plethora of genes involved in mammary differentiation and lactation in mice; but, apparently, the combination of those cues are more important in stimulating the expression of caseins, xanthine oxidoreductase, and several genes involved in milk protein synthesis, as well as genes coding for proteins involved in packaging and transport [138]. Finally, the recognized differences among species prompts a call for caution when extrapolating findings in one species to another [139].

Studies about regulation of other minor milk proteins are limited. For instance lactoferrin expression is known to be induced during mastitis (e.g., [140]) and lactoferrin expression increases dramatically after treatment of mammary epithelial cells with bacteria lipopolysaccharides or double stranded RNA through PKC, NF-kappaB, and MAPK pathways [141]. Transcript abundance of LTF is also under control of a specific miRNA (miR-214) [142]. Beta-lactoglobulin in sheep is regulated by the milk protein binding factor (MPBF/Stat5)[143]. The MPBF mediates the prolactin signal transduction in the lactating mammary gland by binding to gamma-interferon activation site DNA elements [144]. Finally, butyrophilin expression appears to be strongly under the control of Akt1 [145]. The Akt genes are serinethreonine protein kinase with a role in multiple pathways, including insulin signaling. The Akt proteins are essential for milk synthesis, as shown by the lack of production of all main milk components in Akt1 and Akt2-deficient mice [146]. The role of the three known Akt isoforms is different in the mammary gland, with Akt1 being the most important for lactogenesis [147].

In summary, the data presented in Figures 1 and 2, together with the understanding we have so far about the regulation in expression of milk protein, support a model were milk protein genes are coordinately expressed by concerted action of several hormones, cell-tocell interaction, basement membrane, and ECM components. Those act ultimately through signaling pathways (e.g., Jak-STAT, insulin) that activate transcription factors (e.g., GR, STAT5, CEBPB, MPBF) that in turn drive increased expression of genes. There are likely 
complex interactions among those factors that still need to be studied in detail. A more complete picture may be obtained by investigating all the above factors simultaneously. This may be achieved using system biology approaches.

\section{Networks encompassing insulin signaling and mTOR control milk protein synthesis: the missing link with nutrition}

\subsection{Introduction}

As described above, milk protein synthesis is sensitive to energy level in the diet probably due to the increase in insulin and energy available for the costly process of assembling amino acids into proteins. A role for insulin in milk protein synthesis was suggested to be only indirect [108]. This suggestion made sense considering that blood insulin drops substantially during late pregnancy-early lactation. This hormonal pattern is relatively consistent in cattle [4,148], sheep [149] and rats [150]. Despite the decrease of insulin, a role of this hormone in synthesis of the main milk constituents, particularly protein and lactose, in the bovine mammary gland was proposed more than 40 years ago [35]. Recent work has demonstrated a pivotal role of insulin in regulating milk protein synthesis both in the cow [39] and mouse [38].

\subsection{How insulin affects milk protein synthesis}

The mechanisms of insulin in regulating milk protein synthesis can be multiple, direct and indirect; however, the major activity of insulin occurs at two main steps of milk protein synthesis. The first step involves the control of gene expression of milk proteins and the second involves the regulation of translation. For the former, it is well-known that insulin has a strong positive role in activation of STAT5 through increase phosphorylation of the transcription factor [151]. In addition, expression of ELF5, the gene coding for a co-activator and amplifier of STAT5 signaling (see above), is induced by insulin in cattle and mouse mammary tissues $[38,39]$. Those are direct or indirect effects of insulin on control of milk protein expression through STAT5-ELF5. The second role for insulin controlling milk protein synthesis is by regulating amount of translation via the mammalian target of rapamycin (mTOR) pathway.

\subsection{Role of mTOR on regulation of protein synthesis: brief overview}

A master role of mTOR (particularly mTORC1 among the two mTOR complexes) in the regulation of protein synthesis, particularly translation, in all tissues of mammals has been well defined [152]. A simplified model of the role of mTOR in protein synthesis is summarized in Figure 3.

Protein synthesis is basically inhibited by the association of the un-phosphorylated eukaryotic translation initiation factor $4 \mathrm{E}$ binding protein 1 (4EBP1) with the eukaryotic translation initiation factor $4 \mathrm{E}$ (eIF4E), preventing the formation of the translation initiation complex. The increase in insulin signaling increases specific phosphorylation of mTOR. This 


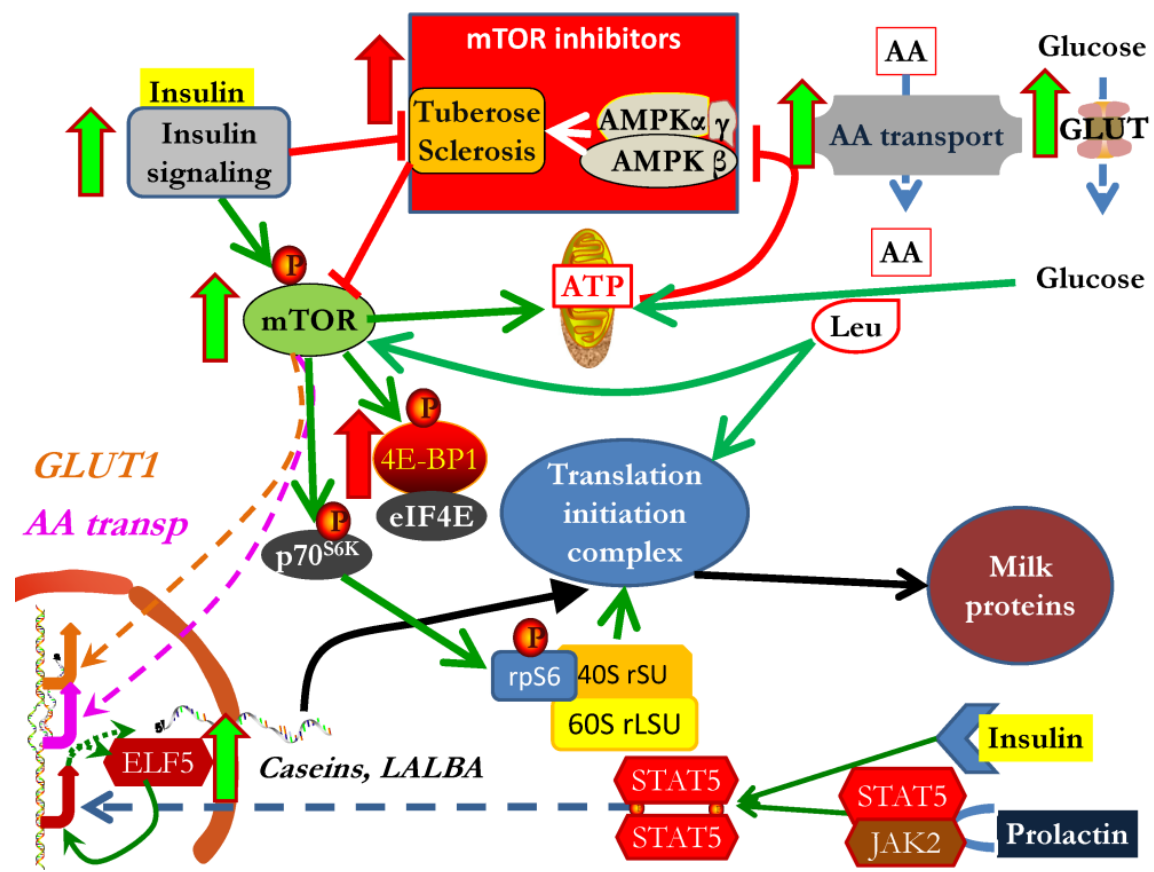

Figure 3. Simplified model of milk protein synthesis regulation by insulin-mTOR pathways (see detailed model in [4]). Green arrows denote activation or positive effect; dashed arrows denote either transport or indirect effect on transcription. Red cap flat lines denote inhibition. Phosphorylation is denoted by a round orange shape. When the mTOR complex is not activated the non-phosphorylated eukaryotic translation initiation factor $4 \mathrm{E}$ binding protein 1 (4E-BP1) binds eukaryotic translation initiation factor $4 \mathrm{E}$ (eiF4E) preventing protein synthesis. The mTOR complex is formed and activated by phosphorylation through the insulin signaling and enhanced by amino acids (particularly Leu). When the mTOR complex is activated it phosphorylates 4E-BP1 at multiple sites which results in release of the eiF4E. Once released, eiF4E forms a complex with other eukaryotic translation initiation factors that in turn bind the $40 \mathrm{~S}$ ribosomal subunit initiating translation. The mTOR also induces translation by two additional mechanisms: indirectly activating the $40 \mathrm{~S}$ ribosomal subunit through phosphorylation of RPS6-p70-protein kinase (p7056K) that in turn phosphorylates the RPS6 enhancing its activity (RPS6 is part of the 40S complex and the increase in RPS6 activity increase 40S complex activity as well); and indirectly preventing the inhibition of the translation elongation. The activity of mTOR complex is inhibited by the dimer formed by the two tuberous sclerosis (TSC1 and TSC2) proteins. The TSC complex is directly inhibited by insulin. Among others, the TSC complex is activated by AMP-activated protein kinase (AMPK). The latter is induced by low level of energy (i.e., higher AMP). The level of energy in mammary is mostly determined by glucose and AA availability to be metabolized into the TCA cycle. Thus, the increase in glucose import (availability of energy) can prevent inhibition of protein synthesis by inhibiting AMPK. At the same time, the activation of mTOR complex increases expression of glucose transporter GLUT1. In addition, mTOR appears to directly induce the mitochondrial ATP synthesis. The activation of transcription of milk protein synthesis by Jak2-Stat5 is also reported, where binding of prolactin and insulin to their receptors induces the phosphorylation of STAT5. Upon phosphorylation, STAT5 dimers translocate to the nucleus and induce transcription of several genes including ELF5 and genes coding for milk proteins. ELF5 protein enhance the activity of STAT5 
increasing transcription of milk protein genes. Vertical arrows denote increased gene expression of components of reported protein complexes during lactation in bovine as observed in [4]. Vertical green arrows denote protein complex with likely increase in abundance during lactation which activity increases protein synthesis. Vertical red arrows denote protein complex with likely increase in abundance during lactation which activity inhibits protein synthesis.

activates the formation of the mTOR complex that in turn phosphorylates 4EBP1 at multiple sites allowing release of eiF4E. Once released, eiF4E forms the translation initiation complex with other translation initiation factors. The complete translation initiation complex then binds the $40 S$ ribosomal subunit forming the 435 pre-initiation complex and initiate translation of mRNA into protein [153]. Besides the above described mechanism, the activated mTOR complex enhances translation by additional mechanisms. A first mechanism is the increase activation of the $40 \mathrm{~S}$ ribosomal subunit through phosphorylation of the ribosomal protein S6 kinase (S6K1) which in turn phosphorylates the ribosomal protein S6 (RPS6, a component of the 40S ribosomal subunit) enhancing its activity. A second mechanism is the inhibition through phosphorylation of the eukaryotic elongation factor-2 kinase (EEF2K). The active un-phosphorylated EEF2K inhibits translation by hindering the activity of the elongation factor 2 (eEF2); thus, inhibition of EEF2K frees eEF2 thereby boosting translation. A third mechanism is through an increase of cellular energy production by enhancing expression of glucose transporter 1 and some of the AA transporters, and by improving mitochondrial ATP synthesis [154]. This in turn provides energy in the form of ATP for the translation but also prevents the inhibition of mTOR through the AMPK (see below).

The mTOR complex is chiefly inhibited by the tuberous sclerosis (TSC) complex $[152,155]$. The TSC complex is activated by several factors in coordination with AMPK [152, 156, 157]. The latter is activated by AMP level and the amount of AMP is determined by low intracellular energy level (i.e., higher AMP). The AMPK increases the TSC complex phosphorylation activating it and, consequently, inhibiting mTOR complex [158].

Interestingly, the mTOR complex is indirectly activated by AA, particularly leucine [153]. Besides activation of mTOR, leucine enhances overall protein synthesis via additional mechanisms [153, 159, 160].

\subsection{How insulin and mTOR cross-talk control translation of milk protein}

Several lines of evidence support a pivotal role of mTOR in milk protein synthesis in mice and cows (some of the studies carried out in cows are summarized in Table 2). Toerien and Cant measured phosphorylation status and abundance of several mTOR-related proteins in bovine mammary tissue and observed that lactating compared to non-lactating bovine mammary tissue is characterized by a higher abundance of eukaryotic translation initiation factor 2 alpha (eIF2 $\alpha$ ) protein, eIF4E protein, and the 4EBP1-eIF4E complex, percentage of eIF4E protein in the 4EBP1-eIF4E complex, and phosphorylation of RPS6 compared to nonlactating bovine mammary [161]. Bovine mammary acini cultured in lactogenic hormones and in a nutrient-rich medium (i.e., high glucose and 4-fold the concentration of amino acids 


\begin{tabular}{lllll}
\hline $\begin{array}{l}\text { Molecular branch } \\
\text { studied }\end{array}$ & $\begin{array}{l}\text { Tissue or } \\
\text { cell type }\end{array}$ & Main objective* & Main conclusions* & Reference \\
\hline $\begin{array}{l}\text { Protein } \\
\text { phosphorylation }\end{array}$ & $\begin{array}{l}\text { Mammary } \\
\text { tissue biopsy }\end{array}$ & $\begin{array}{l}\text { Role of dietary AA and } \\
\text { starch fed to lactating cows } \\
\text { on MPS }\end{array}$ & $\begin{array}{l}\text { mTOR and RPSK6 } \\
\text { phosphorylation is enhanced by } \\
\text { starch and AA }\end{array}$ & {$[28]$}
\end{tabular}

$\begin{array}{lll}\text { Protein } & \text { MacT cells } \\ \text { phosphorylation } \quad \begin{array}{l}\text { Role of the level of essential } \\ \text { AA availability and insulin } \\ \text { on phosphorylation of } \\ \text { several mTOR pathways } \\ \text { proteins and MPS }\end{array} \\ \end{array}$

\section{Essential AA enhance MPS rate} by enhancing phosphorylation of [169] 4EBP1 and eEF2

\section{Phosphorylation of mTOR and}

\begin{tabular}{l|l}
$\begin{array}{l}\text { Protein } \\
\text { phosphorylation }\end{array}$ MacT cells & $\begin{array}{l}\text { Role of specific essential AA } \\
\text { on phosphorylation and } \\
\text { MPS }\end{array}$
\end{tabular}

$\begin{array}{lll}\begin{array}{l}\text { Protein } \\ \text { phosphorylation }\end{array} & \text { Mammary } & \text { Role of mRNA translation } \\ \text { and mRNA } & \text { tissue } & \text { on MPS regulation } \\ \text { expression } & & \end{array}$

RPS6K decreases in the absence of leucine and isoleucine, and leads to lower protein synthesis rate
Lactating mammary tissue is associated with greater expression of RPS6, RPS6K, and [161] eIF isoforms, thus, they play a key role in MPS

\begin{tabular}{l|ll}
$\begin{array}{l}\text { Protein } \\
\text { Phosphorylation }\end{array}$ & $\begin{array}{l}\text { Mammary } \\
\text { tissue biopsy }\end{array}$ & $\begin{array}{l}\text { Role of mTOR signaling in } \\
\text { nutritional regulation of } \\
\text { MPS }\end{array}$
\end{tabular} $\begin{aligned} & \begin{array}{l}\text { Intravenous essential AA and } \\
\text { glucose infusion enhance MPS } \\
\text { via increased phosphorylation of } \\
\text { mTOR }\end{array} \\
& \end{aligned}$

\begin{tabular}{|c|c|c|}
\hline $\begin{array}{l}\text { Protein } \\
\text { phosphorylation }\end{array}$ & $\begin{array}{l}\text { Primary } \\
\text { mammary } \\
\text { epithelial } \\
\text { cells }\end{array}$ & $\begin{array}{l}\text { Role of mTOR signaling in } \\
\text { nutritional and hormonal } \\
\text { regulation of MPS }\end{array}$ \\
\hline
\end{tabular}

Nutrients and hormones are capable of regulating MPS through phosphorylation of the mTOR signaling pathway

\begin{tabular}{l|lll} 
Protein & MacT cells \\
phosphorylation & Role of IGF-1 on mTOR & $\begin{array}{l}\text { Exogenous IGF-1 increased } \\
\text { phosphorylation and } \\
\text { regulation of MPS }\end{array}$ & $\begin{array}{l}\text { RPS6K and mTOR } \\
\text { phosphorylation and stimulated } \\
\text { global protein synthesis }\end{array}$
\end{tabular}

$\begin{array}{ll}\text { Mammary expression } & \text { with mammary protein } \\ \text { tissue biopsy } & \begin{array}{l}\text { synthesis during the } \\ \text { lactation cycle }\end{array}\end{array}$

Expression profile of the

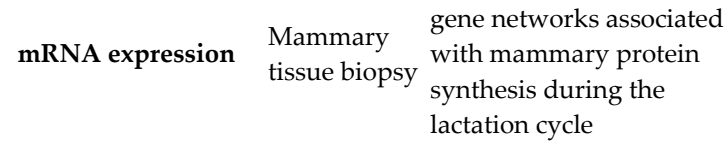

Regulation of mammary protein synthesis during lactation occurs via mTOR and involves adaptations in insulin signaling, glucose transport, and amino acid uptake.

*Amino acid(s) = AA; MPS = milk protein synthesis

Table 2. Published molecular studies of bovine mammary milk protein synthesis regulation. 
found in plasma of well-fed cows) had an increase of S6K1 and 4EBP1 phosphorylation and dissociation between 4EBP1 and eIF2E [29]. Mixtures of all AA or Leu alone in medium strongly affects synthesis of beta-lactoglobulin in mammary epithelial cells of the mouse and the cow, with all AA being more potent than Leu alone [162]. The latter study demonstrated that synthesis of beta-lactoglobulin in bovine cells was associated with phosphorylation of 4EBP1 and S6K1 and that the major effect on protein synthesis of all AA or Leu was through mTOR. Media containing Leu increased milk protein synthesis, while Lys, His, Thr, or the combination of those AA decreased milk protein synthesis up to $65 \%$ via dephosphorylation of S6K1[163]. Infusion of His and Met+Lys did not depress milk protein synthesis in bovine mammary tissue and Leu infusion only had a numerical increase in protein synthesis, but Leu and Met+Lys increased phosphorylation of S6K1 and RPS6 [164]. In the latter study, the infusion of all 10 essential AA plus glucose or glucose alone enhanced milk protein synthesis in dairy cows to the same extent. Both infusions significantly decreased eIF2 phosphorylation but the AA plus glucose also significantly increased phosphorylation of S6K1 and RPS6. This last study highlighted a crucial role for glucose in milk protein synthesis, probably through insulin signaling and not involving mTOR. A positive relationship between mTOR phosphorylation and the fractional protein synthesis rates was also observed in MAC-T cells [165]. The same study showed that leucine and isoleucine are the only AA that significantly increased the phosphorylation of mTOR and S6K1.

The positive response in milk protein synthesis in dairy cows to increasing energy content of the diet is probably elicited through greater phosphorylation of RPS6 by insulin- mTOR signaling as recently demonstrated with abomasal starch infusions [28]. Besides insulin, insulin-like growth factor, growth hormone, leptin, and prolactin appear to increase protein synthesis in bovine mammary through the mTOR pathway [166-168].

\subsection{How insulin and mTOR control bovine milk protein synthesis: an overall model suggested by transcriptomics analysis}

As also described above, we previously proposed a model detailing the networks of factors involved in the regulation of milk protein synthesis in the bovine through the mTOR signaling pathway [4]. Figure 3 represents a simplified version of the proposed model plus main findings from an experiment performed where expression of genes coding for the main players in the insulin-mTOR signaling and other proteins involved in protein synthesis were measured from pregnancy to end of the subsequent lactation in bovine mammary gland [4]. The bovine mammary gland during lactation had a significant, but rather modest, increase in expression of $\mathrm{mTOR}$ (FRAP1), EIF4E, and EEF2, all genes coding for proteins involved in enhancing protein synthesis, but also several genes coding for proteins involved in the negative regulation of protein synthesis were up-regulated, such as one of the 4EBP isoforms (which bind eIF4E) and both TSC genes.

The above observations, together with data from other studies as described above, indicated that the bovine mammary gland during lactation increases slightly the abundance of the 
main players in the regulation of translation, however, due to the increase in expression of inhibitors, protein synthesis may be basically inhibited and mostly driven by phosphorylation that activate the proteins involved in the mTOR pathway and other translational-related proteins. Interestingly, we observed a significant increase in expression during lactation of genes coding for several proteins involved in the insulin signaling, such as the insulin receptor and insulin receptor substrate 1, as well genes coding for several of the insulin down-stream factors, such as AKT3 and 3-phosphoinositide dependent protein kinase-1. Those data indicated that insulin signaling capacity is increased overall in mammary during lactation. In addition, we observed a large increase in expression during lactation of several AA transporters, particularly the one transporting branched-chain amino acids and the one related to mTOR activity (e.g., see leucine activity on mTOR above), as well as the three glucose transporters known to be important in bovine mammary [4]. The large increase in expression of those transporters strongly supports the known increase in mammary uptake of glucose and AA during lactation; however, this also suggest that the energy level inside the mammary gland increases, thereby preventing the indirect mTOR inhibition by AMPK (mostly through the use of AA, see [34]).

Collectively, the observations described above allow us to propose that mammary gland protein synthesis is basically inhibited, however the activity of insulin and the increased energy inside the mammary gland on the one hand induces the activity of the mTOR complex and on the other hand prevents its inhibition, with the end result of enhancing translation of genes coding for milk proteins. This model appears to explain many of the findings from other laboratories, as well as the consistent observed increase in milk protein content through energy in the diet (i.e., this augment energy availability and insulinemia). Considering that dairy cattle experience a sort of insulin insensitivity in tissues other than mammary gland during lactation [170], the low level of insulinaemia observed during lactation might be overridden in the mammary tissue by an increase in insulin signaling capacity occurring as a result of increasing abundance of key proteins in the insulin signaling. Besides insulin, as mentioned above, other hormones such as the insulin-like growth factor (IGF1, which is known to decrease during lactation compared to pregnancy in dairy cows) and growth hormone (GH) can enhance the activity of mTOR and, as consequence, milk protein synthesis. Overall the data suggest a system involving insulin (and likely IGF and GH) and mTOR that allows the mammary gland to fine-tune regulate the milk protein synthesis based on energy availability. The sensitivity of mTOR to AA can open up the possibility of increasing milk protein synthesis by providing a large amount of AA, particularly leucine and other branched-chain amino acid, in the diet with the aim of increasing mTOR activity. Studies discussed above provide support for such an approach but the exclusive use of AA in this case is not enough and might be detrimental if there is not also a concomitant increase in energy in the diet in the form of carbohydrates [28]. Contrary to observations in the bovine, there is not significant increase in expression of insulin receptor and FRAP during lactation in the porcine mammary gland [171]; however, phosphorylation studies are not available in this species to provide conclusions about the activity of mTOR during lactation. 
One finding from the gene expression experiment mentioned above [4] was the lack of increase and even a decrease in expression of ribosomal proteins. This appears to contradict the overall increase in protein synthesis during lactation compared with pregnancy observed in the ruminant $[9,10,164]$, as well the monogastric [65] mammary gland. The use of large transcriptome analyses might provide further clues and allow for development of testable hypotheses.

\section{Unbiased transcriptome: novel findings on mammary protein synthesis by large transcriptomics analysis}

The mammary gland is one of the tissues that changes the most morphologically and functionally during the lifetime of an active procreative female. The plethora of phenomena happening in this tissue during all the developmental phases make it suitable for study by 'omics' technologies; particularly useful has been application of microarray technology to study gene and miRNA expression. Several studies have been published about the use of microarray technologies to investigate transcriptomics adaptation of mammary gland during development, lactation, and involution (some references among others [34, 172-176]). Also the use of microarrays to study the miRNA in mammary gland development has seeing an increase in popularity [177-179].

Recently we have performed a large transcriptomics analysis of the bovine mammary gland from pregnancy to the end of subsequent lactation [34]. For the purpose of providing a functional interpretation of the data we have used the Dynamic Impact Approach (DIA) [89]. This method allows for an interpretation of the impact and the effect (i.e., increase or decrease) on biological functions inferred by the transcriptomics changes. The results of pathways analysis indicated that the most impacted and induced pathways during lactation were related to metabolism, with, among others, an overall increase in the synthesis of lactose, synthesis of lipids, and production of glycans [34]. Interestingly, and unexpectedly, the results indicated that the protein synthesis was not highly impacted and was overall inhibited during lactation. This was mostly due to an overall reduction in expression of ribosomal proteins [34]. However, the data also indicated a large increase of protein export and an increase of protein processing in the endoplasmic reticulum [34]. In order to evaluate if the reduction of overall protein synthesis capacity in mammary tissue during lactation is a unique feature of the bovine or it is also common to other species we have here performed a functional analysis of microarray data generated in mouse [91] and pig mammary tissue [92] during pregnancy and lactation using the DIA and compared with the results of the same analysis carried out in the bovine mammary tissue using data from the above mentioned experiment [34].

The interpretation of the transcriptomics data in the mouse and pig and the comparisons between species face several limitations. For instance the transcriptomics data from mouse and pig can be affected by the large change in proportion between parenchyma and mammary fat pad. In the mouse, the proportion of fat pad can be $>60 \%$ of the entire mammary gland at the beginning of pregnancy but is $<20 \%$ at peak lactation, while 
epithelial cells may make up $30 \%$ and $80 \%$ of the tissue, respectively, in the same timeframe $[176,180]$. In primiparous gilts there is a decrease of percentage of mammary lipid weight from ca. $90 \%$ at the beginning of pregnancy [181] to ca. $45 \%$ at the end of lactation [182]. In multiparous dairy cows the change in proportion of fat pad and epithelial tissue is limited with small fluctuations around ca. $75 \%$ of epithelial [58, 183]. However, the change in percentage of epithelial tissue during the 2 last days of pregnancy compared to full lactation in the mouse is only about $10 \%$ (from ca. 70 to $80 \%$ ), and in the pig the fat content of the mammary gland decreases only from ca. $60 \%$ to ca. $50 \%$ from the last 3 weeks prior parturition to peak lactation, indicating that the change in tissue composition has probably a minor effect on the gene expression data in that timeframe.

Figure 4 offers a comparison of the number of differentially expressed genes (DEG) and the DIA results of pathways associated with milk protein synthesis in mouse [91], pig [92], and dairy cow [34] from the end of pregnancy to mid- to late-lactation (peak lactation for pig and cow but midway during a consistent increase in milk yield in mouse). From that comparison the mouse and cow had a greater transcriptomics adaptation to lactation relative to the pig. In the mouse, most of the DEG were down-regulated and the application of a 2-fold cut-off clearly indicated that most of the genes highly affected by lactation were down-regulated. In the pig, most of the DEG were up-regulated while in the bovine there was an equivalent number of up- and down-regulated DEG; however, when a 2-fold cut-off was applied in the bovine we observed a larger proportion of DEG with a large change to be up-regulated. Those comparisons suggest that the mouse and bovine mammary glands rely heavily on a change in transcription of a large number of genes in order to initiate, increase, and maintain lactation. Surprisingly, expression of most of the genes in the mouse mammary gland was significantly down-regulated in order to "allow" for lactation, in spite of the relatively large milk production and protein synthesis rate (see above and Table 1). This concept was previously proposed by the analysis of a larger dataset in the mouse [175]. In contrast, the bovine mammary gland requires a large increase in expression of several genes in order to activate lactogenesis. Due to the large number of highly affected down-regulated genes in the mouse, most of the pathways were deemed to be inhibited by the DIA analysis, while in the pig and cow most of the pathways were estimated to be induced (results not shown).

Among the pathways selected for their putative importance in milk protein synthesis the DIA results suggested that the mouse mammary gland was featured by a large decrease of protein degradation, suggested by the 'Proteasome' pathway (being one of the 10 most impacted pathways and inhibited in mouse), but also by a decrease in abundance of protein synthesis machinery components as well capacity for charging tRNA with amino acids (see 'Ribosome' and 'Aminoacyl-tRNA biosynthesis' in Figure 4). Other selected pathways had no apparent induction, or a slight inhibition such as for 'Jak-STAT' and 'Insulin' signaling pathways, or an evident inhibition as for the 'SNARE interactions in vesicular transport' (Figure 4). In the pig, the components of the mammary protein synthesis machinery and those for protein degradation were not largely affected by lactation, particularly for the 
'Ribosome', while the other pathways were highly impacted and induced the day after parturition, except for 'Jak-STAT' and 'Insulin' signaling pathways (Figure 4). As observed previously by analysis of the same dataset but with more time points and using a more strong statistical approach [34], for the bovine mammary gland the components of the protein synthesis machinery were induced just before parturition followed by a continuous reduction, while the charging of amino acids to tRNA appeared to be only slightly induced during lactation. The export of protein, and to a lesser magnitude the 'Protein processing in the endoplasmic reticulum', was largely impacted and induced during lactation in this species (Figure 4). The signaling pathways related to protein synthesis in the bovine had a greater impact during lactation compared to the monogastrics, with a clear induction of the 'Jak-STAT signaling' and slight inhibition of both 'mTOR signaling' and 'Insulin signaling' pathways (Figure 4).

A reduction of the protein synthesis machinery was a common feature between the mouse and cow. As discussed above the reduction of the components of the protein synthesis machinery in the cow, but even more importantly in the mouse with its tremendous level of milk protein synthesis per mass of mammary gland (see Table 1), is a curious paradox. In contrast, measurement of the ribosomal proteins in mammary tissue of rabbits and sheep (reviewed in [184]) indicated an increase in quantity and formation of polyribosomes in lactating vs. non-lactating mammary tissue.

The mouse produces a large amount of milk per body weight or per weight of mammary tissue, larger than cow or pig (Table 1). In mice the mammary RNA/DNA ratio increases significantly during lactation $[184,185]$ and the peak in the percentage of protein in milk is reached at ca. 10 days postpartum [186], but milk yield, and total milk protein yield, increases until the end of lactation (ca. 20 day in milk) [186]. In the mouse mammary gland the amount of protein doubles and the rate of protein synthesis triples from end of pregnancy (18 day of pregnancy or 2 days prior parturition) to the beginning of lactation (3 day in milk), and protein content increases 4-fold and protein synthesis rate increases 8-fold from end of pregnancy to 15 day in milk [65]. Similarly, rat acinar cells have a ca. 9-fold increase in synthesis of secreted proteins and ca. 5-fold increase of non-secreted proteins in early lactation [187]. Interestingly, the moment of maximum protein content of the mouse milk seems to coincide with the greatest inhibition of the 'Proteasome' and 'Ribosome' pathways (Figure 4).

In the cow the maximum percentage of milk protein occurs at the end of lactation but the milk protein yield reaches a plateau at around 30 day in milk and remains at that level for up to 6 months [4]. As for the mouse and other species (e.g., pig, see [188]) RNA increases around 2-fold at peak lactation relative to pregnancy [189]. In the dairy goat the rate of protein synthesis in mammary tissue increases ca. 7-fold from dry-off to lactation [9]. There are not equivalent data for the bovine, but it is likely that the protein synthesis rate increases during lactation by the same order of magnitude.

Summarizing the above observations, during lactation there is an increase in RNA, an increase in overall protein synthesis rate, but an apparent decrease in the expression of 

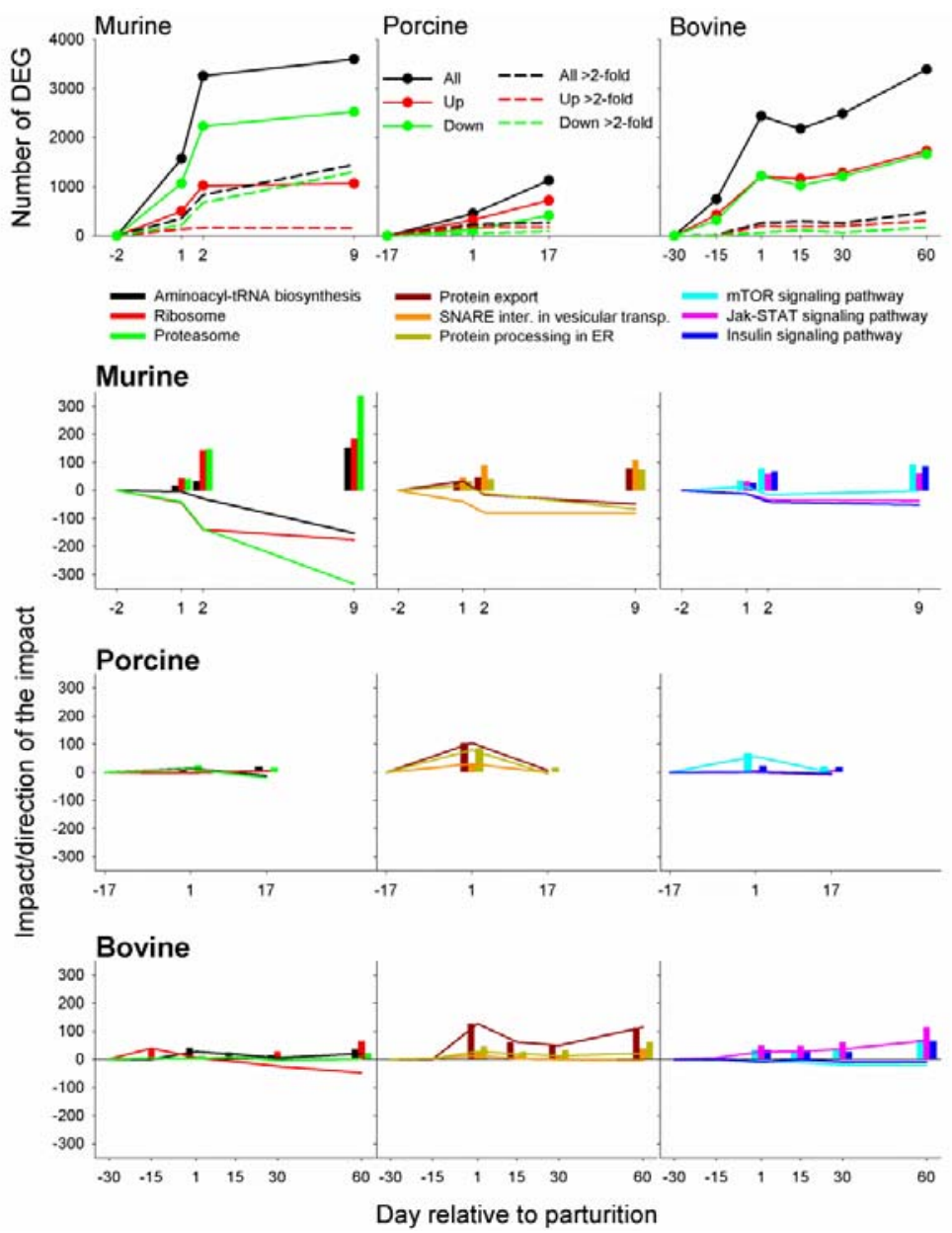

Figure 4. Top panels: number of differentially expressed genes (DEG; FDR $\leq 0.10$, P-value for each time point vs. first time point in pregnancy $\leq 0.05$ ) without fold change cut-off or with 2-fold cut-off (i.e., $>2$ fold). Legend denotes all = all DEG, up = up-regulated DEG, and down = down-regulated DEG with or without 2-fold cut-off. Lower panels: impact and direction of the impact in selected Kyoto Encyclopedia of Genes and Genomes (KEGG; see http://www.genome.jp/kegg/) pathways from the Dynamic Impact Approach (DIA) analysis (see [89]) of genes differentially expressed from pregnancy to mid- and latelactation in the mammary gland of the mouse [91], pig [92], and cow [34]. Original data (i.e., bovine) and data downloaded from the GEO Datasets (at http://www.ncbi.nlm.nih.gov/geo/) as reported in the legend of Figure 1 were statistically analyzed using GeneSpring GX7 with time as fixed effect and with overall false discovery rate (FDR) correction. Day 17 of pregnancy (=-2 day relative to parturition) was used as first time point in pregnancy instead of the 12 day of pregnancy available (i.e., -9 day relative to parturition) from the mouse dataset in order to have all the species at ca. $90 \%$ of the pregnancy term. Datasets containing the FDR correction for the overall time effect plus the fold change and the P-value relative to pregnancy ( $-2 \mathrm{~d}$ for mouse, $-17 \mathrm{~d}$ for pig, and $-30 \mathrm{~d}$ for bovine) for each time point were uploaded to DIA for analysis with the following criteria: FDR $\leq 0.10$, P-value $\leq 0.05$, and $\geq 30 \%$ of microarray coverage of genes in pathways and the whole annotated microarray as background. 
protein synthesis machinery components. In mice the data also suggest a decrease in protein degradation; however, this does not appear to fully account for the increase in overall protein synthesis due to the concomitant reduction of protein synthesis machinery. In addition, the data also suggest that there is a large decrease in expression of many genes in the mouse (Figure 4), but an overall increase in RNA, which is common to all species. As previously suggested [189], the increase in RNA in lactating mammary gland relative to pregnancy is likely due to the dramatic upsurge in expression of a relatively low number of genes coding for high abundant milk proteins, such as caseins and alpha-lactalbumin, and other genes coding for non-specifically secreted proteins, such as fatty acid binding proteins. Therefore, the increase in total RNA is driven by the large increase in expression of a relatively small number of genes. This is also observed in bovine mammary transcriptomics data as evident from Figure 4 (see also [34]).

The decrease, or lack of increase of expression of ribosomal components despite the evident increase in protein synthesis together with the apparent induction of translation during lactation (see Figure 1 and data from other laboratories review above), led us to infer that the decrease of ribosomal components concomitant with a marked increase in mRNA expression of caseins and other milk-specific proteins (Figure 1) is a mechanism for the mammary gland to prioritize at the translational level mRNA coding for proteins related to milk synthesis and secretion rather than non-milk-specific proteins. This suggestion appears to be supported by previous data in mice and goats where competition between secreted milk proteins was observed. Ectopic expression of sheep beta-globulin in mice reduced the expression of other milk proteins (i.e., transcriptional competition) but the amount of total milk protein did not change suggesting that the protein synthesis machinery was already working at full capacity in the lactating mammary tissue [190]. An overall decrease in milk caseins was observed in transgenic goats ectopically expressing high levels of recombinant human butyrylcholinesterase [191]. However, transgenic cows where expression of $\beta$ - and $\kappa-$ casein was ectopically enhanced [192] had a significant (ca. 20\%) increase in milk protein with a change in casein composition of the milk. In fact, it was observed a 2-fold increase in $\kappa$-casein concentration but only ca. $14 \%$ increase of $\beta$-casein content compared to nontransgenic cows. Those data are surprising considering the contrasting observations from the mouse and goat discussed above. However, caseins and most of the milk proteins are synthesized in polyribosomes attached to the endoplasmic reticulum [193]. It is possible that the decrease in expression observed for some of the ribosomal components encompasses components of the cytosolic protein machinery and not, or with a lower proportion, of ribosomal components of the endoplasmic reticulum [4]. This, in turn will provide a greater competitive advantage for the translation of milk protein genes compared to other genes not translated by the polyribosomes. In the case of the study in transgenic cows discussed above [192] the greater increase in $\kappa$-casein but the smaller increase in $\beta$-casein suggests that a competition between the two caseins occurs with a clear advantage toward the $\kappa$-casein, probably due to a sequence/structural difference between the two caseins.

Based on the above observations, and particularly for the mouse and to a less extent for the bovine, we propose that the protein synthesis machinery in the mammary gland is 
purposely decreased during lactation in order to increase the competitive advantage of milk-specific proteins, such as caseins and other secreted proteins, and perhaps for other non-secreted proteins with a pivotal role in mammary gland biology, such as the fatty acid binding protein. This hypothesis can account for the extremely large increase in expression of those milk-specific genes in lactating mammary gland, not only due to an increase in transcription but also an increase in half-life driven by the elongated poly-A tail. This goes along with the well-defined teleological role of the mammary gland, i.e., to produce milk for the offspring. In addition, this phenomenon appears to further support the fine regulation of protein synthesis by lactating mammary gland. It appears that mammary gland attempts on one hand to achieve a "set" composition of the milk, while on the other hand to conserve as much energy as possible: in addition to the basic inhibition of translation which is overcome by the stimulation of the insulin-mTOR pathway, the lowered availability of protein translation machinery provides limitations that in turn can be overcome only by a large availability of precursors (e.g., AA) and energy. This hypothesis is in accord with the above reported finding of higher milk protein when animals have higher energy and AA availability. Another observation that can be made based on the above data is that, if there is a decreased availability of ribosomes but there is a concomitant increase in translation, then there must be an apparent increase in translational efficiency. This can be partly explained by the formation of polyribosomes, but may include other unknown factors, as well.

This hypothesis has a technical consequence. If transcripts are under strong competition for the translational machinery, this means that a discrepancy between data related to mRNA abundance and data related to protein abundance may be expected. As for the dilution effect in quantitative PCR of stably expressed genes due to the high increase in lactationspecific genes [189], the increase in abundance of milk protein genes decreases the accessibility to translational machinery by low-abundant transcripts. Thus, we should expect that a significant increase in expression of low-abundant transcripts from pregnancy to lactation, concomitant with a large increase in high-abundant transcripts, will probably end up being translated in the lactating mammary tissue to the same or reduced extent compared to pregnancy, while the increase in abundant transcripts will be translated to a higher rate, i.e., resulting in a large increase in protein abundance. This may be an important point to consider in interpreting transcriptomics data of the mammary gland during pregnancy and lactation.

\section{Conclusions}

The synthesis and secretion of major proteins found in the milk is a complex phenomenon that still needs to be completely understood. It is clear that those proteins are milk-specific with very minor or no expression in other tissues rather that the lactating (or approaching lactation) mammary gland; furthermore, the expression is present almost exclusively in one type of cell (among more than 200 fully differentiated cells known to compose the mammalian organism): mammary epithelial. The investigations so far have clearly shown that the expression of major milk proteins increases dramatically and in a concerted way during the onset of lactation and remain high until lactation declines (with some exceptions, 
e.g., LALBA in kangaroo). We know that several hormones, the ECM, and the cell-to-cell interactions play a pivotal role in inducing such adaptation with differences between species. We know that nutrition can affect the quantity of milk proteins, with a pivotal role of energy content in the diet. The effect of energy in the diet is mediated by insulin and recent data strongly support a role for the crosstalk between insulin and MTOR in regulating translation. This regulation is chiefly determined by phosphorylation and, with an apparent less importance, by gene transcription. Finally, we have shown that there is an unexpected decrease in expression of ribosomal proteins. This suggests that, at the least in mouse and cow (with a greater emphasis in the former), there is an apparent overall decrease in the protein synthesis machinery despite the known overall increase in protein synthesis. We propose that this is a mechanism for the mammary epithelial cell to increase competitive advantage for translation of milk-related proteins in order to increase the mammary gland's primary function: production of milk.

The control of milk synthesis is still far for being understood. We have not discussed in this chapter the use of bioinformatics to uncover transcriptional networks. This is a semi-in silico approach (i.e., use of a mixture of real data with available previously published information) that allows to uncover which transcription factors are involved in controlling the transcriptomics adaptation. The transcription factors or transcriptional networks suggested by this approach to be pivotal in controlling milk protein synthesis need to be considered with caution. In fact, that information is not conclusive but only indicative; however, this approach allows opening new horizons of research not previously considered.

We are living in an exciting moment in science. The advent of 'omics' tools and, particularly, of the system biology approach, open up new possibilities to investigate the complexity of the mammary adaptations to lactation. The integration of all or some of the available 'omics', such as transcriptomics, proteomics, metabolomics, miRNAomics, single nucleotide polymorphisms, epigenomics, and phosphoproteomics, using and integrative systems biology approach, although not feasible at the moment, is probably what we should implement in the future in order to fully understand the biology of organisms [194], including the control of milk protein synthesis in mammary gland of each species of interest.

\section{Author details}

Massimo Bionaz, Walter Hurley and Juan Loor

Department of Animal Sciences, University of Illinois, Urbana, Illinois, USA

\section{References}

[1] Akers RM (2006) Major advances associated with hormone and growth factor regulation of mammary growth and lactation in dairy cows. J Dairy Sci. 89: 1222-1234

[2] Hadsell DL (2004) Genetic manipulation of mammary gland development and lactation. Advances in experimental medicine and biology. 554: 229-251

[3] Loor JJ, Cohick WS (2009) ASAS centennial paper: Lactation biology for the twenty-first century. Journal of animal science. 87: 813-824 
[4] Bionaz M, Loor JJ (2011) Gene networks driving bovine mammary protein synthesis during the lactation cycle. Bioinform Biol Insights. 5: 83-98

[5] Goff SA (2011) A unifying theory for general multigenic heterosis: energy efficiency, protein metabolism, and implications for molecular breeding. New Phytol. 189: 923-937

[6] Kapahi P (2010) Protein synthesis and the antagonistic pleiotropy hypothesis of aging. Adv Exp Med Biol. 694: 30-37

[7] Baldwin RL, Smith NE, Taylor J, Sharp M (1980) Manipulating metabolic parameters to improve growth rate and milk secretion. J Anim Sci. 51: 1416-1428

[8] Schingoethe DJ, Byers FM, Schelling GT (1988) Nutrient needs during critical periods of the life cycle.In: DC Church, editors. The Ruminant Animal: Digestive, Physiology, and Nutrition, Illinois: Waveland Press. Inc. pp 421-447

[9] Lescoat P, Sauvant D, Danfaer A (1997) Quantitative aspects of protein fractional synthesis rates in ruminants. Reprod Nutr Dev. 37: 493-515

[10] Hanigan MD, France J, Mabjeesh SJ, McNabb WC, Bequette BJ (2009) High rates of mammary tissue protein turnover in lactating goats are energetically costly. J Nutr. 139: $1118-1127$

[11] Kuhn C, Freyer G, Weikard R, Goldammer T, Schwerin M (1999) Detection of QTL for milk production traits in cattle by application of a specifically developed marker map of BTA6. Anim Genet. 30: 333-340

[12] Bequette BJ, Backwell FR, Crompton LA (1998) Current concepts of amino acid and protein metabolism in the mammary gland of the lactating ruminant. J Dairy Sci. 81: 2540-2559

[13] Reynolds CK, Harmon DL, Cecava MJ (1994) Absorption and delivery of nutrients for milk protein synthesis by portal-drained viscera. J Dairy Sci. 77: 2787-2808

[14] Gross J, van Dorland HA, Bruckmaier RM, Schwarz FJ (2011) Performance and metabolic profile of dairy cows during a lactational and deliberately induced negative energy balance with subsequent realimentation. J Dairy Sci. 94: 1820-1830

[15] van Knegsel AT, van den Brand H, Dijkstra J, Tamminga S, Kemp B (2005) Effect of dietary energy source on energy balance, production, metabolic disorders and reproduction in lactating dairy cattle. Reprod Nutr Dev. 45: 665-688

[16] Grieve DG, Korver S, Rijpkema YS, Hof G (1986) Relationship between MilkComposition and Some Nutritional Parameters in Early Lactation. Livestock Production Science. 14: 239-254

[17] Broster WH (1973) Protein-Energy Interrelationships in Growth and Lactation of Cattle and Sheep. Proceedings of the Nutrition Society. 32: 115-122

[18] Sinclair LA, Lock AL, Early R, Bauman DE (2007) Effects of trans-10, cis-12 conjugated linoleic acid on ovine milk fat synthesis and cheese properties. J Dairy Sci. 90: 3326-3335

[19] Cannas A, Pes A, Mancuso R, Vodret B, Nudda A (1998) Effect of dietary energy and protein concentration on the concentration of milk urea nitrogen in dairy ewes. J Dairy Sci. 81: 499-508

[20] Grigor MR, Allan JE, Carrington JM, Carne A, Geursen A, Young D, Thompson MP, Haynes EB, Coleman RA (1987) Effect of dietary protein and food restriction on milk 
production and composition, maternal tissues and enzymes in lactating rats. J Nutr. 117: 1247-1258

[21] Geursen A, Grigor MR (1987) Nutritional regulation of milk protein messenger RNA concentrations in mammary acini isolated from lactating rats. Biochem Int. 15: 873-879

[22] Bauman DE, Harvatine KJ, Lock AL (2011) Nutrigenomics, rumen-derived bioactive fatty acids, and the regulation of milk fat synthesis. Annu Rev Nutr. 31: 299-319

[23] Medeiros SR, Oliveira DE, Aroeira LJ, McGuire MA, Bauman DE, Lanna DP (2010) Effects of dietary supplementation of rumen-protected conjugated linoleic acid to grazing cows in early lactation. J Dairy Sci. 93: 1126-1137

[24] Weerasinghe WM, Wilkinson RG, Lock AL, de Veth MJ, Bauman DE, Sinclair LA (2012) Effect of a supplement containing trans-10,cis-12 conjugated linoleic acid on the performance of dairy ewes fed 2 levels of metabolizable protein and at a restricted energy intake. J Dairy Sci. 95: 109-116

[25] de Veth MJ, Castaneda-Gutierrez E, Dwyer DA, Pfeiffer AM, Putnam DE, Bauman DE (2006) Response to conjugated linoleic acid in dairy cows differing in energy and protein status. J Dairy Sci. 89: 4620-4631

[26] DePeters EJ, Cant JP (1992) Nutritional factors influencing the nitrogen composition of bovine milk: a review. J Dairy Sci. 75: 2043-2070

[27] Hanigan MD, Cant JP, Weakley DC, Beckett JL (1998) An evaluation of postabsorptive protein and amino acid metabolism in the lactating dairy cow. Journal of dairy science. 81: 3385-3401

[28] Rius AG, Appuhamy JA, Cyriac J, Kirovski D, Becvar O, Escobar J, McGilliard ML, Bequette BJ, Akers RM, Hanigan MD (2010) Regulation of protein synthesis in mammary glands of lactating dairy cows by starch and amino acids. J Dairy Sci. 93: 3114-3127

[29] Burgos SA, Dai M, Cant JP (2010) Nutrient availability and lactogenic hormones regulate mammary protein synthesis through the mammalian target of rapamycin signaling pathway. J Dairy Sci. 93: 153-161

[30] Guan X, Pettigrew JE, Ku PK, Ames NK, Bequette BJ, Trottier NL (2004) Dietary protein concentration affects plasma arteriovenous difference of amino acids across the porcine mammary gland. Journal of animal science. 82: 2953-2963

[31] Baumrucker CR (1985) Amino acid transport systems in bovine mammary tissue. J Dairy Sci. 68: 2436-2451

[32] Hanigan MD, Crompton LA, Bequette BJ, Mills JA, France J (2002) Modelling mammary metabolism in the dairy cow to predict milk constituent yield, with emphasis on amino acid metabolism and milk protein production: model evaluation. J Theor Biol. 217: 311330

[33] Mepham TB (1982) Amino acid utilization by lactating mammary gland. J Dairy Sci. 65: 287-298

[34] Bionaz M, Periasamy K, Rodriguez-Zas SL, Everts RE, Lewin HA, Hurley WL, Loor JJ (2012) Old and New Stories: Revelations from Functional Analysis of the Bovine Mammary Transcriptome during the Lactation Cycle. PLoS One. 7: e33268 
[35] Schmidt GH (1966) Effect of insulin on yield and composition of milk of dairy cows. J Dairy Sci. 49: 381-385

[36] Winkelman LA, Overton TR (2010) Is There Opportunity to Boost Milk Protein Production? In: Cornell Nutrition Conference for Feed Manufacturers, (East Syracuse, New York pp 123-132

[37] Herbein JH, Aiello RJ, Eckler LI, Pearson RE, Akers RM (1985) Glucagon, insulin, growth hormone, and glucose concentrations in blood plasma of lactating dairy cows. J Dairy Sci. 68: 320-325

[38] Menzies KK, Lee HJ, Lefevre C, Ormandy CJ, Macmillan KL, Nicholas KR (2010) Insulin, a key regulator of hormone responsive milk protein synthesis during lactogenesis in murine mammary explants. Funct Integr Genomics. 10: 87-95

[39] Menzies KK, Lefevre C, Macmillan KL, Nicholas KR (2009) Insulin regulates milk protein synthesis at multiple levels in the bovine mammary gland. Funct Integr Genomics. 9: 197-217

[40] Te Pas MF, Hoekman AJW, Hulsegge I (2011) From Visual Biological Models Toward Mathematical Models of the Biology of Complex Traits.In: MFW te Pas, H Woelders and A Bannink, editors. Systems Biology and Livestock Science: Wiley-Blackwell. pp 137-159

[41] Liu GE (2011) Recent applications of DNA sequencing technologies in food, nutrition and agriculture. Recent patents on food, nutrition \& agriculture. 3: 187-195

[42] Bruggeman FJ, Westerhoff HV (2007) The nature of systems biology. Trends Microbiol. 15: $45-50$

[43] Barabasi AL, Oltvai ZN (2004) Network biology: understanding the cell's functional organization. Nature reviews. Genetics. 5: 101-113

[44] Schena M, Shalon D, Davis RW, Brown PO (1995) Quantitative monitoring of gene expression patterns with a complementary DNA microarray. Science. 270: 467-470

[45] Wang Z, Gerstein M, Snyder M (2009) RNA-Seq: a revolutionary tool for transcriptomics. Nat Rev Genet. 10: 57-63

[46] Van Dien S, Schilling CH (2006) Bringing metabolomics data into the forefront of systems biology. Molecular systems biology. 2: 20060035

[47] Westerhoff HV, Palsson BO (2004) The evolution of molecular biology into systems biology. Nat Biotechnol. 22: 1249-1252

[48] Palsson B (2009) Metabolic systems biology. FEBS letters. 583: 3900-3904

[49] Loor JJ (2010) Genomics of metabolic adaptations in the peripartal cow. Animal : an international journal of animal bioscience. 4: 1110-1139

[50] Loor JJ, Lin X, Herbein JH (2003) Effects of dietary cis 9, trans 11-18:2, trans 10, cis 1218:2, or vaccenic acid (trans 11-18:1) during lactation on body composition, tissue fatty acid profiles, and litter growth in mice. The British journal of nutrition. 90: 1039-1048

[51] Morag M (1970) Estimation of milk yield in the rat. Laboratory animals. 4: 259-272

[52] Daly SE, Hartmann PE (1995) Infant demand and milk supply. Part 2: The short-term control of milk synthesis in lactating women. Journal of human lactation : official journal of International Lactation Consultant Association. 11: 27-37 
[53] Daly SE, Hartmann PE (1995) Infant demand and milk supply. Part 1: Infant demand and milk production in lactating women. Journal of human lactation : official journal of International Lactation Consultant Association. 11: 21-26

[54] King RH (2000) Factors that influence milk production in well-fed sows. J Anim Sci. 78: 19-25

[55] Hansen AV, Strathe AB, Kebreab E, France J, Theil PK (2012) Predicting milk yield and composition in lactating sows - A Bayesian approach. Journal of animal science.

[56] Bichard M, David PJ (1986) Producing more pigs per sow per year--genetic contributions. Journal of animal science. 63: 1275-1279

[57] Hadsell DL, Parlow AF, Torres D, George J, Olea W (2008) Enhancement of maternal lactation performance during prolonged lactation in the mouse by mouse $\mathrm{GH}$ and longR3-IGF-I is linked to changes in mammary signaling and gene expression. The Journal of endocrinology. 198: 61-70

[58] Capuco AV, Wood DL, Baldwin R, McLeod K, Paape MJ (2001) Mammary cell number, proliferation, and apoptosis during a bovine lactation: relation to milk production and effect of bST. J Dairy Sci. 84: 2177-2187

[59] Moretto VL, Ballen MO, Goncalves TS, Kawashita NH, Stoppiglia LF, Veloso RV, Latorraca MQ, Martins MS, Gomes-da-Silva MH (2011) Low-Protein Diet during Lactation and Maternal Metabolism in Rats. ISRN obstetrics and gynecology. 2011: 876502

[60] Kim SW, Hurley WL, Han IK, Stein HH, Easter RA (1999) Effect of nutrient intake on mammary gland growth in lactating sows. Journal of animal science. 77: 3304-3315

[61] Anderson RR (1975) Mammary gland growth in sheep. Journal of animal science. 41: 118-123

[62] Linzell JL (1972) Milk yield, energy loss in milk and mammary gland weight in different species. Dairy Sci Abstr. 351-360

[63] Mabjeesh SJ, Kyle CE, Macrae JC, Bequette BJ (2000) Lysine metabolism by the mammary gland of lactating goats at two stages of lactation. Journal of dairy science. 83: 996-1003

[64] Guan X, Bequette BJ, Calder G, Ku PK, Ames KN, Trottier NL (2002) Amino acid availability affects amino acid flux and protein metabolism in the porcine mammary gland. The Journal of nutrition. 132: 1224-1234

[65] Millican PE, Vernon RG, Pain VM (1987) Protein metabolism in the mouse during pregnancy and lactation. The Biochemical journal. 248: 251-257

[66] Bequette BJ, Backwell FR (1997) Amino acid supply and metabolism by the ruminant mammary gland. The Proceedings of the Nutrition Society. 56: 593-605

[67] Davies DT, Holt C, Christie WW (1983) The Composition of Milk.In: TB Mepham, editors. Biochemistry of Lactation, Amsterdam: Elsevier Science Publishers B.V. pp 71117

[68] Oftedal OT (1984) Milk composition, milk yield and energy output at peak lactation: a comparative review. Symposia of the Zoological Society of London. 33-85

[69] Bionaz M, Loor JJ (2008) Gene networks driving bovine milk fat synthesis during the lactation cycle. BMC Genomics. 9: 366 
[70] Kolb AF, Huber RC, Lillico SG, Carlisle A, Robinson CJ, Neil C, Petrie L, Sorensen DB, Olsson IA, Whitelaw CB (2011) Milk lacking alpha-casein leads to permanent reduction in body size in mice. PloS one. 6: e21775

[71] Gors S, Kucia M, Langhammer M, Junghans P, Metges CC (2009) Technical note: Milk composition in mice--methodological aspects and effects of mouse strain and lactation day. Journal of dairy science. 92: 632-637

[72] Knight CH, Maltz E, Docherty AH (1986) Milk yield and composition in mice: effects of litter size and lactation number. Comparative biochemistry and physiology. A, Comparative physiology. 84: 127-133

[73] Ley JM, Jenness R (1970) Lactose synthetase activity of alpha-lactalbumins from several species. Archives of biochemistry and biophysics. 138: 464-469

[74] Kumar S, Clarke AR, Hooper ML, Horne DS, Law AJ, Leaver J, Springbett A, Stevenson E, Simons JP (1994) Milk composition and lactation of beta-casein-deficient mice. Proceedings of the National Academy of Sciences of the United States of America. 91: 6138-6142

[75] Jenness R (1979) The composition of human milk. Semin Perinatol. 3: 225-239

[76] Jandal JM (1996) Comparative aspects of goat and sheep milk. Small Ruminant Research. 22: 177-185

[77] Green SW, Renfree MB (1982) Changes in the milk proteins during lactation in the tammar wallaby, Macropus eugenii. Australian journal of biological sciences. 35: 145152

[78] Messer M, Elliott C (1987) Changes in alpha-lactalbumin, total lactose, UDP-galactose hydrolase and other factors in tammar wallaby (Macropus eugenii) milk during lactation. Australian journal of biological sciences. 40: 37-46

[79] Horne DS, Anema S, Zhu X, Nicholas KR, Singh H (2007) A lactational study of the composition and integrity of casein micelles from the milk of the tammar wallaby (Macropus eugenii). Archives of biochemistry and biophysics. 467: 107-118

[80] Cavaletto M, Giuffrida MG, Conti A (2008) Milk fat globule membrane components--a proteomic approach. Advances in experimental medicine and biology. 606: 129-141

[81] Reinhardt TA, Lippolis JD (2006) Bovine milk fat globule membrane proteome. The Journal of dairy research. 73: 406-416

[82] Reinhardt TA, Lippolis JD (2008) Developmental changes in the milk fat globule membrane proteome during the transition from colostrum to milk. J Dairy Sci. 91: 23072318

[83] Affolter M, Grass L, Vanrobaeys F, Casado B, Kussmann M (2010) Qualitative and quantitative profiling of the bovine milk fat globule membrane proteome. Journal of proteomics. 73: 1079-1088

[84] Keenan TW, Mather IH (2006) Intracellular Origin of Milk Fat Globules and the Nature of the Milk Fat Globule Membrane.In: PF Fox and PLH McSweeney, editors. Advanced Dairy Chemistry Vol. 2: Lipids, New York, NY: Springer. pp 137-171

[85] Lonnerdal B (2011) Biological effects of novel bovine milk fractions. Nestle Nutrition workshop series. Paediatric programme. 67: 41-54 
[86] Yen CC, Shen CJ, Hsu WH, Chang YH, Lin HT, Chen HL, Chen CM (2011) Lactoferrin: an iron-binding antimicrobial protein against Escherichia coli infection. Biometals : an international journal on the role of metal ions in biology, biochemistry, and medicine. 24: 585-594

[87] Amini AA, Nair LS (2011) Lactoferrin: a biologically active molecule for bone regeneration. Current medicinal chemistry. 18: 1220-1229

[88] Rhoads RE, Grudzien-Nogalska E (2007) Translational regulation of milk protein synthesis at secretory activation. J Mammary Gland Biol Neoplasia. 12: 283-292

[89] Bionaz M, Periasamy K, Rodriguez-Zas SL, Hurley WL, Loor JJ (2012) A Novel Dynamic Impact Approach (DIA) for Functional Analysis of Time-Course Omics Studies: Validation Using the Bovine Mammary Transcriptome. PloS one. 7: e32455

[90] Faucon F, Rebours E, Bevilacqua C, Helbling JC, Aubert J, Makhzami S, Dhorne-Pollet S, Robin S, Martin P (2009) Terminal differentiation of goat mammary tissue during pregnancy requires the expression of genes involved in immune functions. Physiological genomics. 40: 61-82

[91] Rudolph MC, McManaman JL, Phang T, Russell T, Kominsky DJ, Serkova NJ, Stein T, Anderson SM, Neville MC (2007) Metabolic regulation in the lactating mammary gland: a lipid synthesizing machine. Physiological Genomics. 28: 323-336

[92] Shu DP, Chen BL, Hong J, Liu PP, Hou DX, Huang X, Zhang FT, Wei JL, Guan WT (2012) Global transcriptional profiling in porcine mammary glands from late pregnancy to peak lactation. Omics : a journal of integrative biology. 16: 123-137

[93] Lefevre CM, Digby MR, Whitley JC, Strahm Y, Nicholas KR (2007) Lactation transcriptomics in the Australian marsupial, Macropus eugenii: transcript sequencing and quantification. BMC genomics. 8: 417

[94] Wickramasinghe S, Rincon G, Islas-Trejo A, Medrano JF (2012) Transcriptional profiling of bovine milk using RNA sequencing. BMC genomics. 13: 45

[95] Benjamini Y, Hochberg Y (1995) Controlling the False Discovery Rate - a Practical and Powerful Approach to Multiple Testing. Journal of the Royal Statistical Society Series BMethodological. 57: 289-300

[96] Messer M, Green B (1979) Milk carbohydrates of marsupials. II. Quantitative and qualitative changes in milk carbohydrates during lactation in the tammar wallaby (Macropus eugenii). Australian journal of biological sciences. 32: 519-531

[97] Nicholas K, Simpson K, Wilson M, Trott J, Shaw D (1997) The tammar wallaby: a model to study putative autocrine-induced changes in milk composition. Journal of mammary gland biology and neoplasia. 2: 299-310

[98] Phillippy BO, McCarthy RD (1979) Multi-origins of milk serum albumin in the lactating goat. Biochimica et biophysica acta. 584: 298-303

[99] Shamay A, Homans R, Fuerman Y, Levin I, Barash H, Silanikove N, Mabjeesh SJ (2005) Expression of albumin in nonhepatic tissues and its synthesis by the bovine mammary gland. Journal of dairy science. 88: 569-576

[100] Piccinini R, Binda E, Belotti M, Dapra V, Zecconi A (2007) Evaluation of milk components during whole lactation in healthy quarters. J Dairy Res. 74: 226-232 
[101] Vorbach C, Capecchi MR, Penninger JM (2006) Evolution of the mammary gland from the innate immune system? Bioessays. 28: 606-616

[102] Zapico P, Gaya P, De Paz M, Nunez M, Medina M (1991) Influence of breed, animal, and days of lactation on lactoperoxidase system components in goat milk. Journal of dairy science. 74: 783-787

[103] Loor JJ, Moyes KM, Bionaz M (2011) Functional adaptations of the transcriptome to mastitis-causing pathogens: the mammary gland and beyond. Journal of mammary gland biology and neoplasia. 16: 305-322

[104] Elliot JI, Senft B, Erhardt G, Fraser D (1984) Isolation of lactoferrin and its concentration in sows' colostrum and milk during a 21-day lactation. Journal of animal science. 59: 1080-1084

[105] Cheng JB, Wang JQ, Bu DP, Liu GL, Zhang CG, Wei HY, Zhou LY, Wang JZ (2008) Factors affecting the lactoferrin concentration in bovine milk. Journal of dairy science. 91: 970-976

[106] Whetstone HD, Hurley WL, Davis CL (1986) Identification and characterization of a fatty acid binding protein in bovine mammary gland. Comparative biochemistry and physiology. B, Comparative biochemistry. 85: 687-692

[107] Rosen JM, Wyszomierski SL, Hadsell D (1999) Regulation of milk protein gene expression. Annual review of nutrition. 19: 407-436

[108] Neville MC, McFadden TB, Forsyth I (2002) Hormonal regulation of mammary differentiation and milk secretion. J Mammary Gland Biol Neoplasia. 7: 49-66

[109] Forsyth IA (1986) Variation among species in the endocrine control of mammary growth and function: the roles of prolactin, growth hormone, and placental lactogen. Journal of dairy science. 69: 886-903

[110] Amenomori Y, Chen CL, Meites J (1970) Serum prolactin levels in rats during different reproductive states. Endocrinology. 86: 506-510

[111] Jahn GA, Edery M, Belair L, Kelly PA, Djiane J (1991) Prolactin receptor gene expression in rat mammary gland and liver during pregnancy and lactation. Endocrinology. 128: 2976-2984

[112] Mizoguchi Y, Yamaguchi H, Aoki F, Enami J, Sakai S (1997) Corticosterone is required for the prolactin receptor gene expression in the late pregnant mouse mammary gland. Molecular and cellular endocrinology. 132: 177-183

[113] Mepham TB (1987) Physiology of lactation (Milton Keynes ; Philadelphia: Open University Press)

[114] McVey WR, Jr., Williams GL (1991) Mechanical masking of neurosensory pathways at the calf-teat interface: endocrine, reproductive and lactational features of the suckled anestrous cow. Theriogenology. 35: 931-941

[115] Zwald NR, Weigel KA, Chang YM, Welper RD, Clay JS (2005) Genetic evaluation of dairy sires for milking duration using electronically recorded milking times of their daughters. Journal of Dairy Science. 88: 1192-1198

[116] Rijnkels M (2002) Multispecies comparison of the casein gene loci and evolution of casein gene family. Journal of mammary gland biology and neoplasia. 7: 327-345 
[117] Zhao FQ, Adachi K, Oka T (2002) Involvement of Oct-1 in transcriptional regulation of beta-casein gene expression in mouse mammary gland. Biochimica et biophysica acta. 1577: $27-37$

[118] Groner B (2002) Transcription factor regulation in mammary epithelial cells. Domestic animal endocrinology. 23: 25-32

[119] Reichenstein M, Rauner G, Barash I (2011) Conditional repression of STAT5 expression during lactation reveals its exclusive roles in mammary gland morphology, milkprotein gene expression, and neonate growth. Molecular reproduction and development. 78: 585-596

[120] Hay ED (1993) Extracellular matrix alters epithelial differentiation. Current opinion in cell biology. 5: 1029-1035

[121] Jolivet G, Pantano T, Houdebine LM (2005) Regulation by the extracellular matrix (ECM) of prolactin-induced alpha s1-casein gene expression in rabbit primary mammary cells: role of STAT5, C/EBP, and chromatin structure. Journal of cellular biochemistry. 95: 313-327

[122] Du JY, Chen MC, Hsu TC, Wang JH, Brackenbury L, Lin TH, Wu YY, Yang Z, Streuli CH, Lee YJ (2012) The RhoA-Rok-myosin II pathway is involved in extracellular matrixmediated regulation of prolactin signaling in mammary epithelial cells. Journal of cellular physiology. 227: 1553-1560

[123] Streuli CH, Bailey N, Bissell MJ (1991) Control of mammary epithelial differentiation: basement membrane induces tissue-specific gene expression in the absence of cell-cell interaction and morphological polarity. The Journal of cell biology. 115: 1383-1395

[124] Kumura H, Tanaka A, Abo Y, Yui S, Shimazaki K, Kobayashi E, Sayama K (2001) Primary culture of porcine mammary epithelial cells as a model system for evaluation of milk protein expression. Bioscience, biotechnology, and biochemistry. 65: 2098-2101

[125] Zavizion B, Gorewit RC, Politis I (1995) Subcloning the MAC-T bovine mammary epithelial cell line: morphology, growth properties, and cytogenetic analysis of clonal cells. Journal of dairy science. 78: 515-527

[126] Zhou Y, Akers RM, Jiang H (2008) Growth hormone can induce expression of four major milk protein genes in transfected MAC-T cells. Journal of dairy science. 91: 100108

[127] Huynh HT, Robitaille G, Turner JD (1991) Establishment of bovine mammary epithelial cells (MAC-T): an in vitro model for bovine lactation. Experimental cell research. 197: 191-199

[128] Yang J, Kennelly JJ, Baracos VE (2000) The activity of transcription factor Stat5 responds to prolactin, growth hormone, and IGF-I in rat and bovine mammary explant culture. J Anim Sci. 78: 3114-3125

[129] Yang J, Kennelly JJ, Baracos VE (2000) Physiological levels of Stat5 DNA binding activity and protein in bovine mammary gland. J Anim Sci. 78: 3126-3134

[130] Wheeler TT, Broadhurst MK, Sadowski HB, Farr VC, Prosser CG (2001) Stat5 phosphorylation status and DNA-binding activity in the bovine and murine mammary glands. Mol Cell Endocrinol. 176: 39-48 
[131] Oakes SR, Naylor MJ, Asselin-Labat ML, Blazek KD, Gardiner-Garden M, Hilton HN, Kazlauskas M, Pritchard MA, Chodosh LA, Pfeffer PL, Lindeman GJ, Visvader JE, Ormandy CJ (2008) The Ets transcription factor Elf5 specifies mammary alveolar cell fate. Genes \& development. 22: 581-586

[132] Oakes SR, Hilton HN, Ormandy CJ (2006) The alveolar switch: coordinating the proliferative cues and cell fate decisions that drive the formation of lobuloalveoli from ductal epithelium. Breast cancer research : BCR. 8: 207

[133] Travers MT, Barber MC, Tonner E, Quarrie L, Wilde CJ, Flint DJ (1996) The role of prolactin and growth hormone in the regulation of casein gene expression and mammary cell survival: relationships to milk synthesis and secretion. Endocrinology. 137: $1530-1539$

[134] Streuli CH, Edwards GM (1998) Control of normal mammary epithelial phenotype by integrins. J Mammary Gland Biol Neoplasia. 3: 151-163

[135] Ben Chedly H, Boutinaud M, Bernier-Dodier P, Marnet PG, Lacasse P (2010) Disruption of cell junctions induces apoptosis and reduces synthetic activity in lactating goat mammary gland. Journal of dairy science. 93: 2938-2951

[136] Singh K, Molenaar AJ, Swanson KM, Gudex B, Arias JA, Erdman RA, Stelwagen K (2012) Epigenetics: a possible role in acute and transgenerational regulation of dairy cow milk production. Animal : an international journal of animal bioscience. 6: 375-381

[137] Li X, Zhao X (2008) Epigenetic regulation of mammalian stem cells. Stem cells and development. 17: 1043-1052

[138] Stiening CM, Hoying JB, Abdallah MB, Hoying AM, Pandey R, Greer K, Collier RJ (2008) The effects of endocrine and mechanical stimulation on stage I lactogenesis in bovine mammary epithelial cells. Journal of dairy science. 91: 1053-1066

[139] Bionaz M, Loor JJ (2008) Comparative MammOmics ${ }^{\mathrm{TM}}$ of milk fat synthesis in Mus musculus vs. Bos taurus. J Dairy Sci. 91: 566-567

[140] Moyes KM, Drackley JK, Morin DE, Bionaz M, Rodriguez-Zas SL, Everts RE, Lewin HA, Loor JJ (2009) Gene network and pathway analysis of bovine mammary tissue challenged with Streptococcus uberis reveals induction of cell proliferation and inhibition of PPARgamma signaling as potential mechanism for the negative relationships between immune response and lipid metabolism. BMC Genomics. 10: 542

[141] Li Y, Limmon GV, Imani F, Teng C (2009) Induction of lactoferrin gene expression by innate immune stimuli in mouse mammary epithelial HC-11 cells. Biochimie. 91: 58-67

[142] Liao Y, Du X, Lonnerdal B (2010) miR-214 regulates lactoferrin expression and proapoptotic function in mammary epithelial cells. The Journal of nutrition. 140: 1552-1556

[143] Burdon TG, Demmer J, Clark AJ, Watson CJ (1994) The mammary factor MPBF is a prolactin-induced transcriptional regulator which binds to STAT factor recognition sites. FEBS letters. 350: 177-182

[144] Watson CJ, Miller WR (1995) Elevated levels of members of the STAT family of transcription factors in breast carcinoma nuclear extracts. British journal of cancer. 71 : 840-844

[145] LaRocca J, Pietruska J, Hixon M (2011) Akt1 is essential for postnatal mammary gland development, function, and the expression of Btn1a1. PloS one. 6: e24432 
[146] Chen CC, Boxer RB, Stairs DB, Portocarrero CP, Horton RH, Alvarez JV, Birnbaum MJ, Chodosh LA (2010) Akt is required for Stat5 activation and mammary differentiation. Breast cancer research : BCR. 12: R72

[147] Maroulakou IG, Oemler W, Naber SP, Klebba I, Kuperwasser C, Tsichlis PN (2008) Distinct roles of the three Akt isoforms in lactogenic differentiation and involution. Journal of cellular physiology. 217: 468-477

[148] Rhoads RP, Kim JW, Leury BJ, Baumgard LH, Segoale N, Frank SJ, Bauman DE, Boisclair YR (2004) Insulin increases the abundance of the growth hormone receptor in liver and adipose tissue of periparturient dairy cows. The Journal of nutrition. 134: 1020-1027

[149] Vernon RG, Clegg RA, Flint DJ (1981) Metabolism of sheep adipose tissue during pregnancy and lactation. Adaptation and regulation. The Biochemical journal. 200: 307314

[150] Martin-Hidalgo A, Huerta L, Alvarez N, Alegria G, Del Val Toledo M, Herrera E (2005) Expression, activity, and localization of hormone-sensitive lipase in rat mammary gland during pregnancy and lactation. Journal of lipid research. 46: 658-668

[151] Le MN, Kohanski RA, Wang LH, Sadowski HB (2002) Dual mechanism of signal transducer and activator of transcription 5 activation by the insulin receptor. Mol Endocrinol. 16: 2764-2779

[152] Wang X, Proud CG (2006) The mTOR pathway in the control of protein synthesis. Physiology (Bethesda). 21: 362-369

[153] Kimball SR, Jefferson LS (2006) New functions for amino acids: effects on gene transcription and translation. Am J Clin Nutr. 83: 500S-507S

[154] Schieke SM, Phillips D, McCoy JP, Jr., Aponte AM, Shen RF, Balaban RS, Finkel T (2006) The mammalian target of rapamycin (mTOR) pathway regulates mitochondrial oxygen consumption and oxidative capacity. J Biol Chem. 281: 27643-27652

[155] Proud CG (2007) Signalling to translation: how signal transduction pathways control the protein synthetic machinery. Biochem J. 403: 217-234

[156] Feng Z, Zhang H, Levine AJ, Jin S (2005) The coordinate regulation of the p53 and mTOR pathways in cells. Proc Natl Acad Sci U S A. 102: 8204-8209

[157] Inoki K, Ouyang H, Zhu T, Lindvall C, Wang Y, Zhang X, Yang Q, Bennett C, Harada Y, Stankunas K, Wang CY, He X, MacDougald OA, You M, Williams BO, Guan KL (2006) TSC2 integrates Wnt and energy signals via a coordinated phosphorylation by AMPK and GSK3 to regulate cell growth. Cell. 126: 955-968

[158] Sarbassov DD, Ali SM, Sabatini DM (2005) Growing roles for the mTOR pathway. Curr Opin Cell Biol. 17: 596-603

[159] Backer JM (2008) The regulation and function of Class III PI3Ks: novel roles for Vps34. Biochem J. 410: 1-17

[160] MacKenzie MG, Hamilton DL, Murray JT, Taylor PM, Baar K (2009) mVps34 is activated following high-resistance contractions. J Physiol. 587: 253-260

[161] Toerien CA, Cant JP (2007) Abundance and phosphorylation state of translation initiation factors in mammary glands of lactating and nonlactating dairy cows. J Dairy Sci. 90: 2726-2734 
[162] Moshel Y, Rhoads RE, Barash I (2006) Role of amino acids in translational mechanisms governing milk protein synthesis in murine and ruminant mammary epithelial cells. J Cell Biochem. 98: 685-700

[163] Prizant RL, Barash I (2008) Negative effects of the amino acids Lys, His, and Thr on S6K1 phosphorylation in mammary epithelial cells. J Cell Biochem. 105: 1038-1047

[164] Toerien CA, Trout DR, Cant JP (2010) Nutritional stimulation of milk protein yield of cows is associated with changes in phosphorylation of mammary eukaryotic initiation factor 2 and ribosomal s6 kinase 1. J Nutr. 140: 285-292

[165] Appuhamy JA, Knoebel NA, Nayananjalie WA, Escobar J, Hanigan MD (2012) Isoleucine and leucine independently regulate mTOR signaling and protein synthesis in MAC-T cells and bovine mammary tissue slices. The Journal of nutrition. 142: 484-491

[166] Hayashi AA, Nones K, Roy NC, McNabb WC, Mackenzie DS, Pacheco D, McCoard S (2009) Initiation and elongation steps of mRNA translation are involved in the increase in milk protein yield caused by growth hormone administration during lactation. J Dairy Sci. 92: 1889-1899

[167] Feuermann Y, Shamay A, Mabjeesh SJ (2008) Leptin up-regulates the lactogenic effect of prolactin in the bovine mammary gland in vitro. J Dairy Sci. 91: 4183-4189

[168] Burgos SA, Cant JP (2010) IGF-1 stimulates protein synthesis by enhanced signaling through mTORC1 in bovine mammary epithelial cells. Domest Anim Endocrinol. 38: 211-221

[169] Appuhamy JA, Bell AL, Nayananjalie WA, Escobar J, Hanigan MD (2011) Essential amino acids regulate both initiation and elongation of mRNA translation independent of insulin in MAC-T cells and bovine mammary tissue slices. The Journal of nutrition. 141: 1209-1215

[170] Bell AW, Bauman DE (1997) Adaptations of glucose metabolism during pregnancy and lactation. J Mammary Gland Biol Neoplasia. 2: 265-278

[171] Manjarin R, Steibel JP, Kirkwood RN, Taylor NP, Trottier NL (2012) Transcript abundance of hormone receptors, mammalian target of rapamycin pathway-related kinases, insulin-like growth factor I, and milk proteins in porcine mammary tissue. Journal of animal science. 90: 221-230

[172] Piantoni P, Bionaz M, Graugnard DE, Daniels KM, Everts RE, Rodriguez-Zas SL, Lewin HA, Hurley HL, Akers M, Loor JJ (2010) Functional and gene network analyses of transcriptional signatures characterizing pre-weaned bovine mammary parenchyma or fat pad uncovered novel inter-tissue signaling networks during development. BMC Genomics. 11: 331

[173] Zhao H, Huang M, Chen Q, Wang Q, Pan Y (2011) Comparative gene expression analysis in mouse models for identifying critical pathways in mammary gland development. Breast cancer research and treatment.

[174] Master SR, Hartman JL, D'Cruz CM, Moody SE, Keiper EA, Ha SI, Cox JD, Belka GK, Chodosh LA (2002) Functional microarray analysis of mammary organogenesis reveals a developmental role in adaptive thermogenesis. Molecular endocrinology. 16: 11851203 
[175] Lemay DG, Neville MC, Rudolph MC, Pollard KS, German JB (2007) Gene regulatory networks in lactation: identification of global principles using bioinformatics. BMC Syst Biol. 1: 56

[176] Rudolph MC, McManaman JL, Hunter L, Phang T, Neville MC (2003) Functional development of the mammary gland: use of expression profiling and trajectory clustering to reveal changes in gene expression during pregnancy, lactation, and involution. J Mammary Gland Biol Neoplasia. 8: 287-307

[177] Wang C, Li Q (2007) Identification of differentially expressed microRNAs during the development of Chinese murine mammary gland. Journal of genetics and genomics $=\mathrm{Yi}$ chuan xue bao. 34: 966-973

[178] Avril-Sassen S, Goldstein LD, Stingl J, Blenkiron C, Le Quesne J, Spiteri I, Karagavriilidou K, Watson CJ, Tavare S, Miska EA, Caldas C (2009) Characterisation of microRNA expression in post-natal mouse mammary gland development. BMC genomics. 10: 548

[179] Silveri L, Tilly G, Vilotte JL, Le Provost F (2006) MicroRNA involvement in mammary gland development and breast cancer. Reproduction, nutrition, development. 46: 549556

[180] Wang M, Master SR, Chodosh LA (2006) Computational expression deconvolution in a complex mammalian organ. BMC Bioinformatics. 7: 328

[181] Ji F, Hurley WL, Kim SW (2006) Characterization of mammary gland development in pregnant gilts. Journal of animal science. 84: 579-587

[182] Kim SW, Hurley WL, Han IK, Easter RA (1999) Changes in tissue composition associated with mammary gland growth during lactation in sows. Journal of animal science. 77: 2510-2516

[183] Capuco AV, Akers RM, Smith JJ (1997) Mammary growth in Holstein cows during the dry period: quantification of nucleic acids and histology. J Dairy Sci. 80: 477-487

[184] Denamur R (1974) Ribonucleic acids and ribonucleoprotein particles of the mammary gland.In: BL Larson and VR Smith, editors. Lactation: a comprehensive treatise, New York and London: Academic Press. pp 414-491

[185] Nagasawa H, Yanai R (1976) Mammary nucleic acids and pituitary prolactin secretion during prolonged lactation in mice. The Journal of endocrinology. 70: 389-395

[186] Riley LG, Zubair M, Thomson PC, Holt M, Xavier SP, Wynn PC, Sheehy PA (2006) Lactational performance of Quackenbush Swiss line 5 mice. Journal of animal science. 84: $2118-2125$

[187] Roh SG, Baik MG, Choi YJ (1994) The effect of lactogenic hormones on protein synthesis and amino acid uptake in rat mammary acinar cell culture at various physiological stages. The International journal of biochemistry. 26: 479-485

[188] Kensinger RS, Collier RJ, Bazer FW, Ducsay CA, Becker HN (1982) Nucleic acid, metabolic and histological changes in gilt mammary tissue during pregnancy and lactogenesis. Journal of animal science. 54: 1297-1308

[189] Bionaz M, Loor JJ (2007) Identification of reference genes for quantitative real-time PCR in the bovine mammary gland during the lactation cycle. Physiol Genomics. 29: 312-319 
[190] McClenaghan M, Springbett A, Wallace RM, Wilde CJ, Clark AJ (1995) Secretory proteins compete for production in the mammary gland of transgenic mice. Biochem $\mathrm{J}$. 310 ( Pt 2): 637-641

[191] Baldassarre H, Hockley DK, Olaniyan B, Brochu E, Zhao X, Mustafa A, Bordignon V (2008) Milk composition studies in transgenic goats expressing recombinant human butyrylcholinesterase in the mammary gland. Transgenic Res. 17: 863-872

[192] Brophy B, Smolenski G, Wheeler T, Wells D, L'Huillier P, Laible G (2003) Cloned transgenic cattle produce milk with higher levels of beta-casein and kappa-casein. Nat Biotechnol. 21: 157-162

[193] Homareda H, Komine S (1982) Casein synthesis by mouse polysomes and their messenger ribonucleic acid extracts. J Dairy Sci. 65: 915-919

[194] Wheeler MB, Monaco E, Bionaz M, Tanaka T (2010) The Role of Existing and Emerging Biotechnologies for Livestock Production: toward holism In: Acta Scientiae Veterinariae, pp s463-s484 